\title{
Strategies For Quantifying PET Imaging Data From Tracer Studies of Brain Receptors and Enzymes
}

\author{
Jean Logan \\ Chemistry Department, Brookhaven National Laboratory \\ Upton, NY 11973
}




\section{Introduction}

Positron emission tomography (PET) and single photon emission computed tomography (SPECT) have made possible the in vivo investigation of neuroreceptors, transporters and enzymes that are implicated in disease states such as schizophrenia, Parkinson's disease as well as in addiction and processes associated with aging. Some of the tracers used and the receptors/transporters that they label are: $\left[{ }^{11} \mathrm{C}\right]$ raclopride (Farde et al. 1989; Volkow et al. 1993;

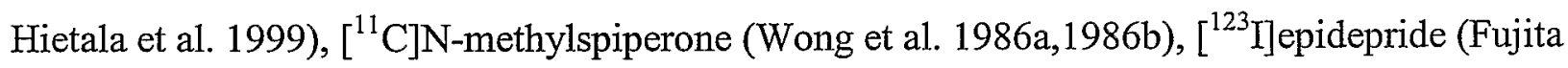
et al. 1999) for the D2 dopamine receptor; $\left[{ }^{11} \mathrm{C}\right]$-Schering 23390 (Farde et al. 1987; Suhara et al 1991), $\left[{ }^{11} \mathrm{C}\right] \mathrm{NNC} 112$ (Abi-Dargham et al. 2000), for the D1 receptor; [ $\left.{ }^{11} \mathrm{C}\right]$ benztropine (Dewey et al. 1993a), scopolamine (Frey et al. 1992), $\left[{ }^{11} \mathrm{C}\right]$ tropanyl benzilate (Koeppe et al. 1994), $\left[{ }^{11} \mathrm{C}\right]$ NMPB (Zubieta et al. 1998), ${ }^{18}$ F]FP-TZTP, (Carson et al. 1998) for the muscarinic cholinergic system; $\left[{ }^{11} \mathrm{C}\right]$ cocaine (Fowler et al. 1989) $\left[{ }^{11} \mathrm{C}\right] \mathrm{d}$-threo methlyphenidate (Volkow et al. 1995; Ding et al. 1994, 1997), for the dopamine transporter; $\left[{ }^{11} \mathrm{C}\right]$ dihydrotetrabenazine (Koeppe et al. 1995), for the vesicular monoamine transporter; $\left[{ }^{11} \mathrm{C}\right]$ carfentanil (Frost et al. 1989) for the opiate receptor; $\left[{ }^{11} \mathrm{C}\right]$ WAY-100635 (Mathis et al.1994; Farde et al.1998), for the 5HT1A; $\left[{ }^{11} \mathrm{C}\right]$ flumazenil (Price et al. 1993) and $\left[{ }^{123} I\right]$ iomazenil (Bremner et al. 2000) for the benzodiazepine receptor. Examples of ligands used for the study of brain enzymes are $\left[{ }^{11} \mathrm{C}\right] \mathrm{L}$ deprenyl and $\left[{ }^{11} \mathrm{C}\right] \mathrm{L}$-deprenyl-D2 (MAO B) (Fowler et al. 1987, 1995), $\left[{ }^{11} \mathrm{C}\right]$ clorgyline (MAO A) (Fowler et al. 1987), and [ ${ }^{11}$ C] PMP (acetylcholinesterase) (Koeppe et al. 1999).

In order to allow comparisons between subjects of measures related to receptor concentration, it is necessary to separate physiological process related to receptor concentration from other processes that influence tracer uptake. In order to do this many methods of varying complexity have been developed and applied. Many are based on one or two tissue compartment models in which uptake into tissue is driven by the plasma concentration of the labelled tracer. The measurements are radioactivity concentration in tissue (PET/SPECT) and plasma radioactivity which is divided into that due to unchanged tracer and its metabolites. In some cases these have been simplified so that a reference region (a region of interest (ROI) from the PET study that is devoid of the receptor/transporter being studied) is used in place of an input function. Also some techniques don't require full dynamic scanning relying on an equilibrium between tissue and blood. 
These models are very simple and most likely represent a combination of processes particularly in the case of enzyme inactivation as occurs with $\left[{ }^{11} \mathrm{C}\right]$ deprenyl and MAO B which is actually a multistep process. Due to the fact that only the total tissue radioactivity can be measured and not its components, the number of identifiable model parameters is limitedgenerally to no more than 4 , if that.

While there are techniques for separately evaluating receptor number and affinity, these experiments are difficult and require the administration of a sufficient amount of drug to block a substantial fraction of receptors. While these studies have the potential for providing important information they will not be discussed here. Most PET/SPECT experiments, particularly in a clinical setting, are in the high specific activity range and the model parameters for reversibly binding ligands are some measure of $B \max ^{\prime} / \mathrm{Kd}$ where $\mathrm{Bmax}^{\prime}$ is taken to be the free receptor concentration and $\mathrm{Kd}$ is the receptor-ligand equilibrium dissociation constant.

When the free receptor/enzyme concentration does not change over the course of the experiment, the model equations are first order linear differential equations which can be solved either numerically or in closed form. Even if the receptor concentration is changing due to a change in neurotransmitter concentration from a drug treatment, these equations can still be solved in the same way but the model parameter related to Bmax' represents some average over the course of the experiment. There are a number of approaches that have been used to evaluate the model parameters. These range from the most complex - optimizing model parameters by solving the model differential equations, a nonlinear least squares approach (NLLSQ), to a ratio of tissue activity in an equilibrium measurement. There are a number of modifications that have been applied to the set of differential equations that simplify the modeling process and in some cases eliminate the necessity of measuring an arterial input function. A review of various modeling techniques and their strengths and weaknesses is the subject of this chapter.

\section{Models}

General models for the description of tracer distribution and binding are given below. $\mathrm{Cp}$ represents the plasma concentration of labelled tracer, $\mathrm{C}_{\mathrm{F}}$ is the free concentration of tracer in brain tissue, $\mathrm{C}_{\mathrm{NS}}$ is the nonspecifically bound tracer. $\mathrm{K}_{1}$ and $\mathrm{k}_{2}$ are the ligand transport constants, plasma to tissue and tissue to plasma, respectively. Model Ia represents regions without specific binding sites. Model IIa adds specifically bound tracer, $\mathrm{C}_{\mathrm{S}}$. Here it is assumed that there is only 
one kind of receptor binding site.

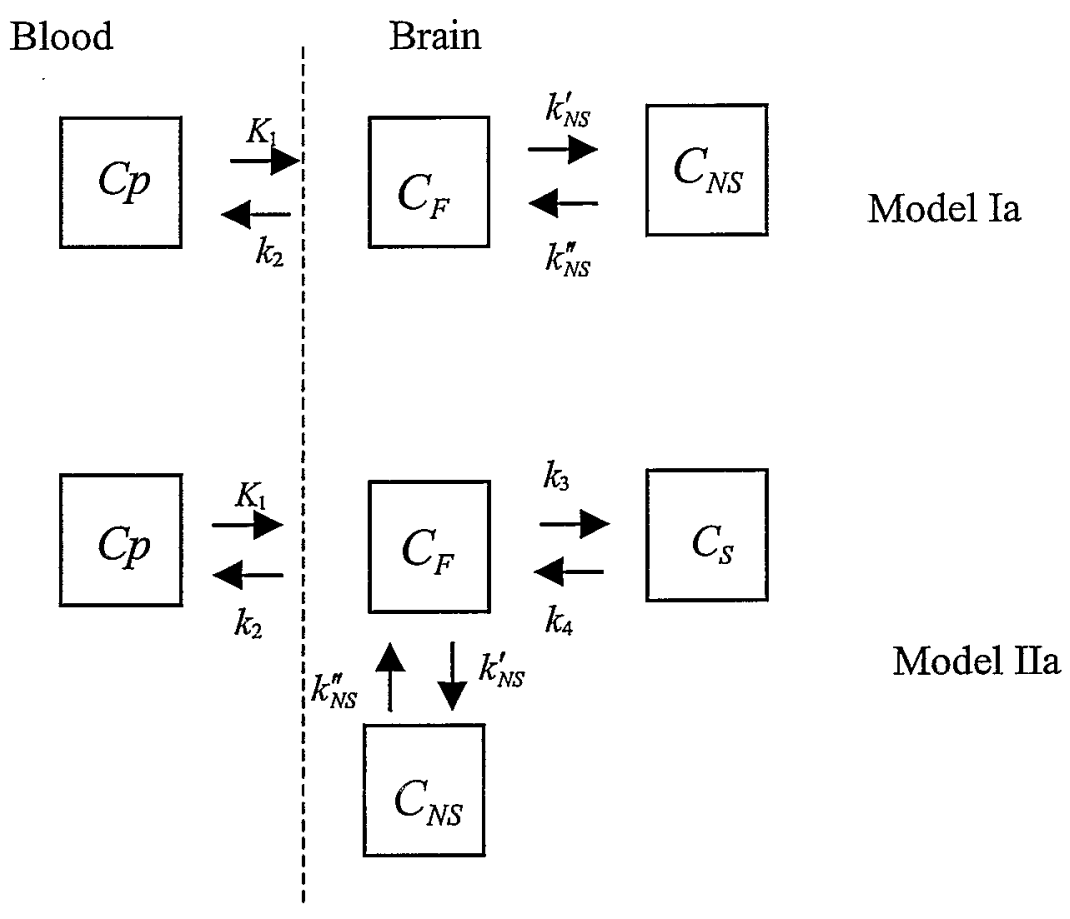

The binding parameters $\mathrm{k}_{\mathrm{Ns}}$ 'and $\mathrm{k}_{\mathrm{NS}}$ " in Models Ia and IIa represent nonspecific (nonsaturable) binding, $\mathrm{k}_{3}$ represents (saturable) binding to specific receptor/transporters and $\mathrm{k}_{4}$ is the receptorligand dissociation constant. A simplification of models I and II is that the constants describing nonspecific binding $\left(\mathrm{k}_{\mathrm{NS}}\right.$ 'and $\left.\mathrm{k}_{\mathrm{NS}}{ }^{\prime \prime}\right)$ are sufficiently greater than the other kinetic constants that the concentration of free ligand is a constant fraction of the total (free plus nonspecifically bound), that is $\mathrm{C}_{\mathrm{F}}=\mathrm{f}_{\mathrm{NS}} C_{1}^{N S}$ where $\mathrm{f}_{\mathrm{NS}}$ is the free fraction (Mintun et al. 1984). With this assumption the models become

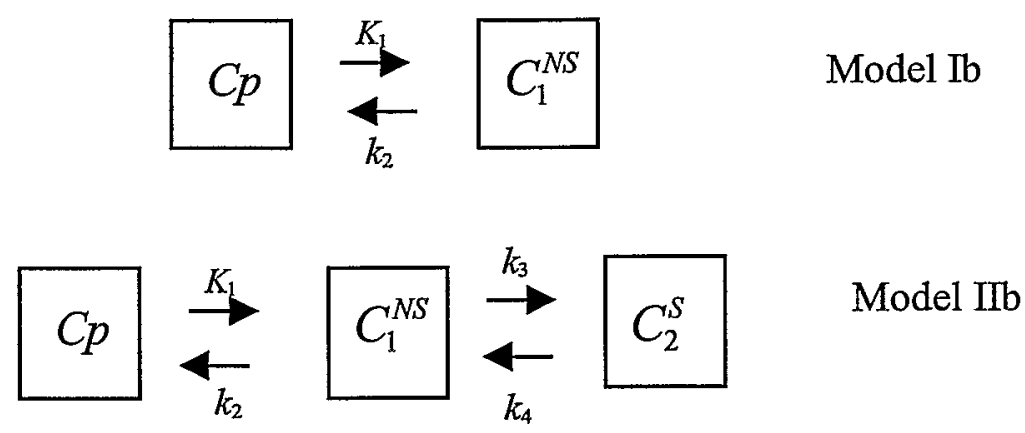

However, it has been found in a number of cases that it is necessary to use 2 tissue compartments 
to described the cerebellum (reference region) (for example Abi-Dargham et al. 2000, Logan et al. 1991, Carson et al. 1998 ) so that the nonspecific consists of two parts - one rapid and one slower with binding constants $\mathrm{k}_{5}$ and $\mathrm{k}_{6}$

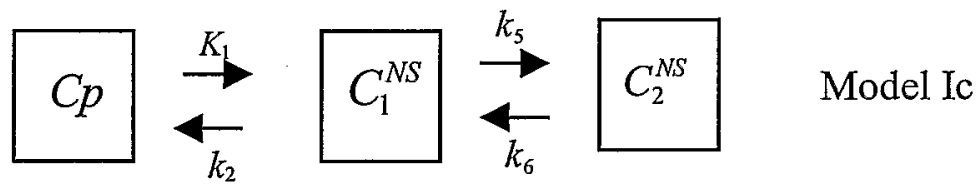

There is the question of whether or not this additional binding is also present in the receptor containing region. In fact, Seeman et al (1990) reported that nonspecific binding of raclopride is greater in the basal ganglia than in cerebellum.

In some cases the binding is irreversible on the time scale of the experiment so that the model becomes

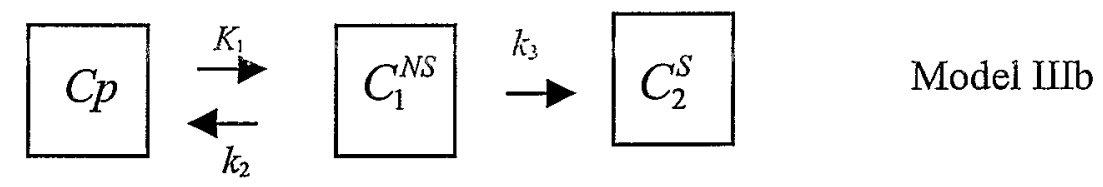

The transport constants $\mathrm{K}_{1}$ (plasma to tissue) and $\mathrm{k}_{2}$ (tissue to plasma) are functions of blood flow and the permeability surface area product, PS. Based on a homogeneous single capillary model in which tissue concentration surrounding the capillary is constant over the time of capillary transit, the transport constants can be related to F and PS as (Crone, 1963; Renkin, 1959; Kety 1951; Patlak and Fenstermacher 1975)

$$
K_{1}=F\left(1-\exp \left(-P S_{1} / F\right)\right) \quad k_{2}=\frac{P S_{2}}{P S_{1}} F\left(1-\exp \left(-P S_{1} / F\right)\right)
$$

More complex models relating tracer transport and flow have been considered by Sawada et al. (1991). The distinction between $\mathrm{PS}_{1}$ and $\mathrm{PS}_{2}$ involves the incorporation of the free fraction in plasma and tissue, that is $\mathrm{PS}_{1}=\mathrm{PSfp}$ where $\mathrm{fp}$ is the free fraction of ligand in plasma and $\mathrm{PS}_{2}=\mathrm{PSf}_{\mathrm{NS}}$ with $\mathrm{f}_{\mathrm{NS}}$ being the free fraction in tissue. The use of $\mathrm{fp}$ and $\mathrm{f}_{\mathrm{NS}}$ presumes that equilibrium between free and bound ligand is rapidly achieved on a time scale shorter than the capillary transit time. The unbound ligand is assumed to pass through the blood brain-barrier by passive diffusion. 
The differential equations of Model IIb, the commonly used model for receptor binding, are given by

$$
\begin{gathered}
\frac{d C_{1}^{N S}}{d t}=K_{1} C p(t)-k_{2} C_{1}^{N S}-k_{o n} f_{N S}\left(B \max -L-N_{B}\right)+k_{4} C_{2}^{S} \\
\frac{d C_{2}^{S}}{d t}=k_{o n}\left(B \max -L-N_{B}\right)-k_{4} C_{2}^{S}
\end{gathered}
$$

The assumption implicit in the model of specific binding is that the receptor occupancy is unchanged during the course of the experiment. The parameter $\mathrm{k}_{3}$ is given by $\mathrm{k}_{3}=f_{\mathrm{NS}} k_{\mathrm{on}}$ (Bmax$N_{B}-L$ ) where Bmax is the total receptor/transporter concentration and $N_{B}$ is the endogenous neurotransmitter concentration. $\mathrm{L}$ is the concentration of unlabelled ligand bound to receptors. In the high specific activity limit $\mathrm{L}$ is negligible compared to Bmax and is neglected. On the other hand $\mathrm{N}_{\mathrm{B}}$ is generally not negligible and can influence the amount of tracer that binds to receptors and hence the measure of receptor availability. How $\mathrm{N}_{B}$ affects the number of binding sites available to the tracer ligand depends upon several factors. If $\mathrm{N}_{\mathrm{B}}$ and the labelled tracer $\left(L^{*}\right)$ both bind to the same site or to overlapping sites on the receptor, then $L^{*}$ will reflect the reduced number of sites. If they don't bind to the same site, then $L^{*}$ will reflect more the total number of sites, although if it doesn't bind to the functional site, it may not necessarily be a good measure of a functional receptor.

In many PET studies drug induced neurotransmitter changes are monitored with tracer ligands. Neurotransmitter competition with labelled tracers has been studied by Dewey et al. (1990, 1993a, 1993b), Innis et al. (1992), Volkow et al. (1994), Laruelle et al. (1997) and others. In these cases $N_{B}$ is changing with time $\left(N_{B}(t)\right)$. Although the model equations are no longer linear, they can be solved as though they were by assuming a "constant" $B \max =\mathrm{Bmax}-\mathrm{N}_{\mathrm{B}}$. Endres and Carson (1998) have considered through simulations how binding characteristics of the tracer affect sensitivity to the changes in neurotransmitter concentration.

- These models are certainly simplifications of the actual binding processes. For example, the binding of $\left[{ }^{11} \mathrm{ClL}\right.$-deprenyl which is an irreversible inhibitor of the enzyme MAO B, is thought to react with the enzyme in the multistep process shown below 


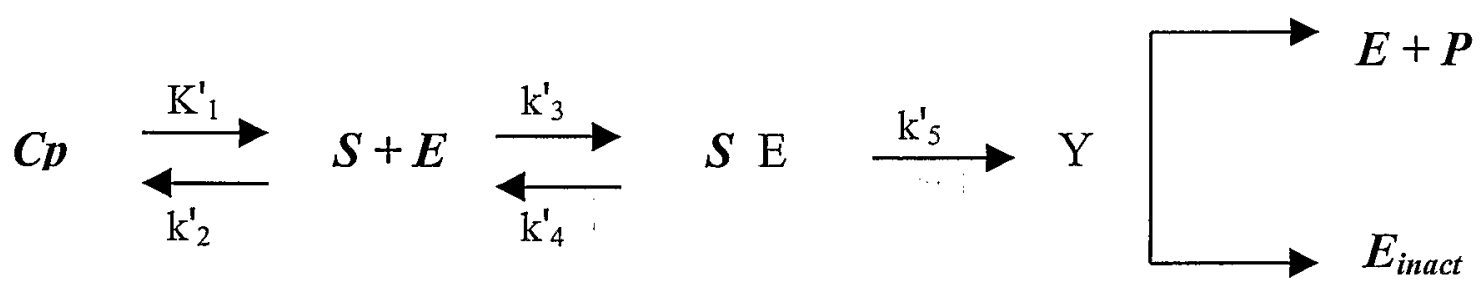

However, since PET measures the sum of all radioactivity sources within an ROI, it is not possible to uniquely determine kinetic constants for all the steps in the process. As a result, the simpler irreversible model with one binding parameter is used for the description of the binding of $\left[{ }^{11} \mathrm{C}\right] \mathrm{L}$ deprenyl. When the concentration E-S is approximately constant, then $k_{3}$ of the irreversible two tissue compartment model (IIIb) corresponds to $\mathrm{k}_{5}^{\prime} \mathrm{k}_{3}^{\prime} /\left(\mathrm{k}_{4}^{\prime}+\mathrm{k}_{5}^{\prime}\right)$ in the above scheme.

Also some ligands are known to bind to more than one receptor/binding site, for example, $\mathrm{N}$ methyl spiperone (NMSP) binds to serotonin receptors as well as dopamine $\mathrm{D}_{2}$ receptors. Another possible complicating factor is the presence of multiple receptor affinity states. Additional binding sites could in theory be added to the model but as with $\left[{ }^{11} \mathrm{C}\right] \mathrm{L}$-deprenyl without additional information it would be difficult to separately identify all components. In such cases $k_{3}$ and $k_{4}$ would reflect multiple components of specific binding. In general the models used to describe PET data represent a macroscopic average of many microscopic processes. The ligand diffuses to the binding site, binds to a receptor, dissociates and rebinds perhaps before diffusing away. Among other things the configuration of the binding sites can contribute to the macroscopic model parameter. There are also some experimental results that suggest that for šme ligands the classical occupancy model based on the free receptor concentration given by $B \max -N_{B}$ is not correct. For example, a decrease in binding of the $D_{2}$ ligand NMSP after reserpine treatment which decreases synaptic DA was observed (Inoue et al. 1991). Furthermore $\left.{ }^{3} \mathrm{H}\right] \mathrm{NMSP}$ binding was increased after MK-801 treatment but $\left[{ }^{3} \mathrm{H}\right]$ raclopride binding was not significantly changed (Inoue et al. 1999a). Inoue et al. (1999b) offer evidence that these ligands bind to different sites on the receptor. Furthermore the receptors appear to form dimers and larger clusters. Differences in the binding properties may be due to the different binding capacities to $\mathrm{D}_{2}$ receptor dimers and monomers. Zawarynski et al. (1998) found that a spiperone derivative labelled only the $\mathrm{D}_{2}$ monomer and a raclopride derivative both the dimer and the monomer. These results and others relating to the occupancy model are discussed by Laruelle (2000). In any case,.for many ligands the models described 
above provide a useful tool for comparing data although they are certainly an approximation to the underlying physiological processes.

\section{Strategies for determining model parameters}

\section{Measures of receptor availability}

Rather than compare individual model parameters which are subject to considerable variablility (Carson et al. 1993), comparison among subjects is usually made by comparing a composite parameter that is a combination of model parameters. For reversible ligands this is either the binding potential (BP) (Mintun et al. 1984), the total tissue distribution volume (DV), the distribution volume ratio (DVR) (the ratio of the DV of a receptor region to that of a reference region without the receptor) or an effective binding potential derived from the DVR. Another possibility is the difference between the receptor DV (DV $\mathrm{ROI})$ and the DV of the reference region $\left(D V_{R E F}\right)$. All of these measures are a function of the free receptor binding sites but they each depend upon assumptions about the constancy of other processes. The binding potential is defined as $B P=\mathrm{Bmax}^{\prime} / K d$ (Mintun et al. 1984). In terms of the model parameters used here it is given by $k_{3} /\left(k_{4} f_{\mathrm{NS}}\right)$ since $k_{3}$ implicitly contains the free fraction $\left(\mathrm{f}_{\mathrm{NS}}\right)\left(k_{3}=k_{\mathrm{on}} \mathrm{Bmax}{ }^{\prime}\right.$ $f_{\mathrm{NS}}$ and $K \mathrm{~d}=k_{\mathrm{off}}\left(k_{\mathrm{on}}\right)$. (In Mintun et al. $1984, f_{\mathrm{NS}}=f_{2}$.) Many researchers define the binding potential as $B P=k_{3} / k_{4}=\mathrm{Bmax}^{\prime} / K d^{\prime}$ where $K d^{\prime}$ includes $f_{\mathrm{NS}}\left(K d^{\prime}=k_{\mathrm{off}} /\left(k_{\mathrm{on}} f_{\mathrm{NS}}\right)=K d / f_{\mathrm{NS}}\right)$. In this case, the assumption is that $f_{\mathrm{NS}}$ is constant and does not contribute to differences in $B P$.

The distribution volume is given by the ratio of the tissue to plasma under equilibrium conditions, that is $\mathrm{DV}=\mathrm{C}_{\mathrm{ROI}} / \mathrm{Cp}, \mathrm{C}_{\mathrm{ROI}}$ is the tissue concentration of a region of interest. For some ligands equilibrium can be achieved and the DV can be measured in this manner (see below). Alternatively, the DV given by (Lassen and Perl, 1979) as

$$
D V=\frac{\int_{0}^{\infty} C_{R O I}(t) d t}{\int_{0}^{\infty} C p(t) d t}
$$

is valid for nonequilibrium experimental conditions. In most cases this is not a practical approach to calculating the DV. The DV can be determined under nonequilibrium conditions directly by graphical analysis described below. The DV can also be determined from the model 
parameters which for the 1 and 2 tissue compartment models (Model $\mathrm{Ib}$ and Model (Tb)) are $\mathrm{K}_{1} / \mathrm{k}_{2}$ and $\mathrm{K}_{1} / \mathrm{k}_{2}\left(1+\mathrm{k}_{3} / \mathrm{k}_{4}\right)$, respectively. If there is a component of slow nonspecific binding in both, then these become $\mathrm{K}_{1} / \mathrm{k}_{2}\left(1+\mathrm{k}_{3} / \mathrm{k}_{4}+\mathrm{k}_{5} / \mathrm{k}_{6}\right)$ and $\mathrm{K}_{1} / \mathrm{k}_{2}\left(1+\mathrm{k}_{5} / \mathrm{k}_{6}\right)$. Since the transport constants are a function of plasma protein binding $\left(\mathrm{PS}_{1}=\mathrm{PS} f \mathrm{p}\right.$ in $\left.\mathrm{Eq}(1)\right)$, the DV also depends upon plasma protein binding. This can be eliminated by independently measuring $f \mathrm{p}$ and removing it from the DV (DV/fp) (Carson et al. 1993). The problem is that generally a large fraction of ligand is bound to plasma proteins so that errors in the determination of $f \mathrm{p}$ can introduce considerable variability into the DV. By basing comparisons on the distribution volume ratio (DVR) the dependence upon plasma protein binding is removed. The DV's can be determined directly by graphical analysis or equilibrium measurement for example. The DVR is then (assuming that the ratio of transport constants is the same for both receptor and reference region)

$$
D V R=\frac{D V_{R O I}}{D V_{R E F}}=1+\frac{k_{3}}{k_{4}}=1+\frac{B m a x^{\prime}}{K d^{\prime}}
$$

The $B P$ can then be calculated indirectly as DVR-1 as opposed to explicitly determining $k_{3}$ and $k_{4}$. The DVR is still a function of nonspecific binding through $f_{\mathrm{NS}}$ in $K d^{\prime}$. If there is a component of slow nonspecific binding in both regions, then the DVR expressed in terms of model parameters is

$$
\frac{K_{1} / k_{2}\left(1+k_{5} / k_{6}+k_{3} / k_{4}\right)}{K_{1}^{R E F} / / k_{2}^{R E F}\left(1+k_{5}^{R E F} / k_{6}^{R E F}\right)}=R_{N S}+\frac{\left(K_{1} / k_{2}\right) k_{3} / k_{4}}{\left(K_{1}^{R E F} / k_{2}^{R E F}\right)\left(1+k_{5}^{R E F} / k_{6}^{R E F}\right)}
$$

where $k_{5}$ and $k_{6}$ refer to the "slow" component of nonspecific binding (see Model Ic). If the ratios $K_{1} / k_{2}$ and $k_{5} / k_{6}$ are the same for both regions, then the binding potential derived from the DVR is $B P=\mathrm{DVR}-1=f^{\prime} k_{3} / k_{4}$ where $f^{\prime}=1 /\left(1+k_{5}^{R E F} / k_{6}^{R E F}\right)$ and $R_{\mathrm{NS}}$ is 1 . Therefore the $B P$ calculated directly by estimating the model parameters could lead to a different value from $B P$ calculated indirectly through the DVR. If a slow component exists in the receptor compartment also, it would most likely be difficult to separate from the receptor binding component and the $B P$ calculated using Model IIb would include both components, overestimating the BP. Subtracting the reference DV from the ROI DV gives $K_{1} / k_{2}(B P)$ defining BP as $k_{3} / k_{4}$. This measure is dependent upon $f \mathrm{p}$ through $K_{1}$ but the dependence upon $f_{\mathrm{NS}}$ has been removed since it appears in both $k_{2}$ and $k_{3}$ and therefore cancels (see Carson et al. 1997). A comparison of 
outcome measures for equilibrium, kinetic and graphical methods is given by Laruelle (2000) (see Table 6 in that article).

For irreversibly binding ligands, receptor availability is contained in model parameter $\mathrm{k}_{3}$. Logan et al. (2000a) found that reproducibility on test/retest for $\left[{ }^{11} \mathrm{C}\right] \mathrm{L}$-deprenyl-D2 significantly improved if comparison is based on the combination parameter $\lambda k_{3}$ where $\lambda=K_{1} / k_{2}$. Graphical analysis (Patlak et al. 1983) of uptake data from irreversible ligands provides an influx constant $\mathrm{Ki}$ given by $K_{1} k_{3} /\left(k_{2}+k_{3}\right)$ which depends upon blood flow (see below).

\section{Modeling Options for Reversible Ligands}

\section{With a measured plasma input function}

The model parameters can be optimized by solving the differential equations using a measured plasma input function and determining the set of values that give the best fit to the data. For a discussion of optimization methods see Carson (1986). The BP and DV can then be determined from the appropriate combination of model parameters. The linearized version of the standard compartment models (Blomqvist 1984; Evans 1987) provide a more efficient method of parameter estimation. The model equations become a set of linear equations. For the one and two tissue compartment models the linear equations (for scan times $t_{i}$ ) are

$$
\begin{gathered}
C_{R O I}\left(t_{i}\right)=K_{1} \int_{0}^{t_{i}} C p d t-k_{2} \int_{0}^{t_{i}} C_{R O I}(t) d t \\
C_{R O I}\left(t_{i}\right)=K_{1}\left(k_{3}+k_{4}\right) \int_{0}^{t_{i}} \int_{0}^{t^{\prime}} C p d t d t^{\prime}-\kappa \int_{0}^{t_{i}} C_{R O I}(t) d t-k_{2} k_{4} \int_{0}^{t_{i}} \int_{0}^{t^{\prime}} C_{R O I}(t) d t d t^{\prime}+K_{1} \int_{0}^{t_{i}} C p d t
\end{gathered}
$$

where $\kappa=\left(k_{2}+k_{3}+k_{4}\right)$.

A more general approach to linear least squares analysis is given by Thie et al (1997). This approach is model independent in that the constants can be determined without reference to a particular model. There are $2 \mathrm{n}$ coefficients $c_{i}$ in which fits to data can be made with $\mathrm{n}=1,2$ or 3 and the optimum number selected based on a statistical analyses (Thie et al. 1997)

$$
C_{R O I}(T)=c_{1} \int_{0}^{T} C p d t-c_{2} \int_{0}^{T} C_{R O I}(t) d t+c_{3} \int_{0}^{T} \int_{0}^{t} C p d t^{\prime} d t-c_{4} \int_{0}^{T} \int_{0}^{t} C_{R O I}(t) d t d t^{\prime}+\text { (if needed) } \iiint
$$

The problem is that the coefficients are function of both blood flow and the receptor parameter. 
Parameter estimates based on the linear forms of the model equations as in Eq (5) are subject to bias because the equation errors, are not statistically independent that is each succeeding one depends upon the previous one (Feng et al. 1993, 1996). In order to overcome the bias problem, Feng et al. (1993) introduced a generalized linear least squares (GLLS) method which removes the bias. The GLLS form of the one tissue model is

$$
C_{1}\left(t_{i}\right)-\hat{k}_{2} e^{-\hat{k}_{2} t_{i}} \otimes C_{1}\left(t_{i}\right)=K_{1} e^{-\hat{k}_{2} t_{i}} \otimes C p\left(t_{i}\right)-k_{2} e^{-\hat{k}_{2} t_{i}} \otimes C_{1}\left(t_{i}\right)
$$

Feng et al have generalized this to more complex models (Feng et al. 1996).

In graphical analysis the set of linear equations describing a general model is transformed into a single equation which becomes linear for time $t>t^{*}$ (Logan et al. 1990). While this is applicable to a multicompartment system, only two parameters are determined, the slope and the intercept which are combinations of the model parameters. The graphical analysis equation for points determined by scan times $t_{\mathrm{i}}$ is

$$
\frac{\int_{0}^{t_{i}} C_{R O I}(t) d t}{C_{R O I}\left(t_{i}\right)}=[D V+V p] \frac{\int_{0}^{t_{i}} C p(t) d t}{C_{R O I}\left(t_{i}\right)}+i n t
$$

where $\mathrm{DV}+\mathrm{Vp}$ is the slope for the linear region which occurs for times $t_{\mathrm{i}}>t^{*}$ and $\mathrm{Vp}$ is the contribution of the tissue blood volume. The condition for linearity of $\mathrm{Eq}(7)$ is that the intercept (int) which for a two tissue compartment model is given by.

$$
-\frac{1}{k_{2}}\left[1+\frac{k_{3}}{k_{4}}\right]-\frac{C_{2}(t)}{k_{4}\left(C_{1}(t)+C_{2}(t)\right)}
$$

is constant. For some time $t>t^{\prime}$, the compartment concentrations follow the plasma concentration so that $\left(C_{1}+C_{2}\right) \propto C p$ and $C_{2} \propto C p$ (the steady state condition) which insures that int is constant since $C p$ cancels. In many cases the intercept becomes constant even before, $\left(C_{1}+C_{2}\right) / C p$ becomes constant. Therefore the graphical method can be applied before the steady state condition becomes valid, when for some time $t^{*}<t^{\prime}$, the ratio $\mathrm{C}_{2} /\left(C_{1}+C_{2}\right)$ varies slowly and is effectively constant. The limiting value of the time dependent portion of the intercept is given by $\frac{C_{2}(t)}{C_{1}(t)+C_{2}(t)} \rightarrow \frac{1}{1+k_{4} / k_{3}}$. The graphical analysis is illustrated in Figure 1 using simulated data with the same DV but with very different kinetics. For the upper curve (Figure 1a), the main contribution to the $\mathrm{DV}$ is from the ratio of transport constants $\lambda=K_{1} / k_{2}$ while for the lower curve the main contribution is from the ratio of binding constants $\left(\mathrm{k}_{3} / \mathrm{k}_{4}=20\right.$ and 5$)$. The 
graphical analysis is illustrated in Figure 1b. Both achieve linearity but with very different times $t^{*}$ which will affect the length of scanning time required to obtain an accurate estimate of the DV.

The graphical method has been extended by Ichise et al. (1999) to account for labelled lipophilic metabolites which could cross the blood-brain barrier, interfering with the quantification of ligand uptake.

Alternatively the DV can be obtained directly by manipulating the plasma levels so that equilibrium is reached. Patlak and Petigrew (1976) developed a method for obtaining infusion schedules to achieve specified blood concentration levels over time. This method has been used in particular to produce a constant input function. Carson et al. (1993) extended this method to include a bolus injection with a continuous infusion to produce a true equilibrium so that the true DV is given by the ratio of tissue to plasma. The advantage is that only a few scans are required and arterial blood sampling is not necessary. Whether this method is appropriate depends upon the kinetics of the tracer. A transient equilibrium between tissue $\left(C_{T}\right)$ and plasma can be achieved after a bolus injection so that $\mathrm{C}_{\mathrm{T}}(\mathrm{t}) / \mathrm{Cp}(\mathrm{t})$ is constant. This however is generally not the true distribution volume but is a function of the rate of plasma clearance (Carson et al. 1993; Logan et al. 1990).

\section{Without a measured plasma input function}

There are several approaches to determining model parameters without an input function. These methods require a reference region, a region devoid of the receptor/transporter or other binding site being studied. Lammertsma et al. (1996) presented a reference region method assuming the reference region could be described by a one tissue compartment model. They derived the following relationship between concentration of tracer in the reference region, $C_{R E F}$ and $C_{T}$, the total tissue concentration for a two compartment model

$$
C_{T}(t)=R_{1}\left[C_{R E F}(t)+a C_{R E F}(t) \otimes \exp (-c t)+b C_{R E F}(t) \otimes \exp (-d t)\right]
$$

where $R_{1}$ is the ratio $K_{1} / K_{1}^{R E F}$, and $a, b, c$, and $d$ are cömbinations of the model parameters, $k_{2}, k_{3}$, and $k_{4}$ and are determined by standard nonlinear regression analysis. A simplified reference tissue model which assumes that the receptor region can also be described by a one tissue compartment is given by the equation (Lammertsma and Hume, 1996) 


$$
C_{T}(t)=R_{1} C_{R E F}(t)+\left[k_{2}-R_{1} k_{2} /(1+B P)\right] C_{R E F}(t) \otimes \exp \left(-k_{2} t /(1+B P)\right)
$$

in which three parameters, $\mathrm{k}_{2}, \mathrm{R}_{1}$ and $\mathrm{BP}$, are to be determined using nonlinear analysis. Gunn et al. (1997) revised this method so that two parameters $R_{1}$ and $\beta$ are determined using a linear least squares optimization for a set of values of $\gamma$

$$
C_{T}(t)=R_{1} C_{R E F}(t)+\beta C_{R E F}(t) \otimes \exp (-\gamma t)
$$

$\gamma$ and $\beta$ are composite parameters corresponding to $\mathrm{Eq}(9)$.

An alternative linearization of the simplified reference tissue method was given by Logan et al. (2001a) as

$$
C_{1}(t)-\hat{k}_{2} e^{-\hat{k}_{2} t} \otimes C_{1}(t)=-k_{2} e^{-\hat{k}_{2} t} C_{1}(t)+\frac{K_{1}}{K_{1}^{R E F}} C_{R E F}(t)-\frac{K_{1}}{K_{1}^{R E F}}\left(k_{2}-k_{2}^{R E F}\right) e^{-k_{2} t} \otimes C_{R E F}(t) \quad(10)
$$

This method is based on the generalized linear least squares method of Feng et al. (1993). There are three constants to be determined by a linear solution, $k_{2}, K_{1} / K_{1}^{R E F}$, and $\left(K_{1} / K_{1}^{R E F}\right)\left(k_{2}-k_{2}^{R E F}\right)$ given an initial estimate, $\hat{k}_{2}$. Generally only a few iterations are required (Feng et al. 1993).

Another method based on a reference region input is a modification of the graphical analysis method (Logan et al. 1996). The DVR can be calculated directly with the graphical method by using data from a reference region $\left(\mathrm{C}_{R E F}(t)\right)$ with an average tissue to plasma efflux constant, $\bar{k}_{2}$ to approximate the plasma integral

$$
\frac{\int_{0}^{T} C_{R O I}(t) d t}{C_{R O I}(t)}=D V R\left[\frac{\int_{0}^{T} C_{R E F}(t) d t+C_{R E F}(T) / \bar{k}_{2}^{R E F}}{C_{R O I}(T)}\right]+i n t^{\prime}
$$

where $i n t^{\prime}$ is $i n t+\delta, \delta$ is the error term given by

$$
\delta=D V R\left(\frac{1}{k_{2}^{R E F}}-\frac{1}{\bar{k}_{2}}\right) \frac{C_{R E F}(T)}{C_{R O I}(T)}
$$

When $\left[\frac{D V R}{k_{2}}\right] \frac{C_{R E F}(T)}{C_{R O I}(T)}$ is small and/or reasonably constant the term containing $\bar{k}_{2}^{R E F}$ in Eq(11) can be neglected.

Ichise has proposed an alternative to $\mathrm{Eq}(11)$ which is a multilinear regression (Ichise et al. 1996). This method appears to provide the same results as Eq(11) with $\bar{k}_{2}=\infty$. When lipophilic 
metabolites are present in tissue, Ichise has proposed a method requiring a single blood sample to generate the DV from the DVR calculated using the reference tissue with the contaminating metabolites (Ichise, et al. 1999).

Farde et al. $(1986,1989)$ determined Bmax $/ \mathrm{Kd}^{\prime}$ for raclopride at a transient equilibrium point of the specifically bound ligand (when $d C_{2}^{S} / d t=0$ ). $C_{2}^{S}$ was defined as the difference between the radioactivity in the putamen and that in the cerebellum. At high specific activity $B m a x^{\prime} / K d^{\prime}=C_{2}^{S} / C_{1}^{N S}$ where the free ligand $\left(C_{1}^{N S}\right)$ is the cerebellar (reference region) concentration at the point $d C_{2}^{S} / d t=0$. Farde et al. (1989) also used this technique to estimate separately Bmax' and $\mathrm{Kd}^{\prime}$ by doing additional studies at lower specific activities and using a Scatchard analysis. Although this method is vulnerable to errors in the determination of the point at which $d C_{2}^{S} / d t=0$, comparable values of $\mathrm{Bmax}^{\prime}$ and $\mathrm{Kd}^{\prime}$ were found for both the pseudo equilibrium and kinetic methods for $\left[{ }^{11} \mathrm{C}\right]$ raclopride. Another factor limiting the usefulness of this technique to other tracers is error in the estimation of $C_{2}^{S}$ due to a difference in blood flow between the two regions (Logan et al. 1997).

\section{Modeling options for irreversible ligands}

\section{With a measured plasma Input function}

Irreversibly binding ligands (Model IIIb) are essentially trapped for the time course of the scanning procedure. Information about receptor availability is contained in model parameter $k_{3}$. The three model parameters can be estimated using an optimization procedure and solving the differential equations directly. Different approaches to optimizing $k_{3}$ are illustrated in Koeppe et al. (1999) for the ligand $\left[{ }^{11} \mathrm{C}\right] \mathrm{PMP}$ which binds irreversibly to acetylcholinesterase. These included unconstrained estimation of all three parameters and constrained estimation of $k_{3}$ by fixing the $K_{1} / k_{2}$ ratio. This assumes that the ratio is relatively constant across the brain, an assumption which has been found to hold for a number of PET tracers.

Alternatively, a model independent graphical method (Blasberg et al. 1979; Gjedde 1981; and Patlak et al.1983; Patlak and Blasberg 1985) evaluates the rate constant (Ki) for the transfer of tracer from plasma to the irreversible compartment. The equation for this is 


$$
\frac{C_{R O I}(T)}{C p(T)}=K i \frac{\int_{0}^{T} C p(t) d t}{C p(T)}+(V e+V p)
$$

which is linear for the times $T>t^{*}$ when $V e$, the distribution volume of the reversible part (the ratio of the concentration in the reversible compartment to plasma) is constant (for Model $\mathrm{mb}$ this is $C_{I} / C p$ ). Relating this to the two tissue compartment irreversible model, the influx constant $K i$ can be expressed as $K i=\frac{K_{1} k_{3}}{k_{2}+k_{3}}=\frac{K_{1} \lambda k_{3}}{K_{1}+\lambda k_{3}}$. Ki is expressed in terms of two parameters, $K_{I}$ which represents the transport of ligand from plasma to tissue and the combination parameter $\lambda k_{3}$ which also contains the ratio of transport constants $\left(\lambda=K_{1} / k_{2}\right)$. Although $K_{1}$ and $k_{2}$ are functions of blood flow, $\lambda$ is not. From $\mathrm{Eq}(5)$ it can be seen that $K i$ depends upon $K_{l}$ (blood flow) as well as free receptor/enzyme concentration (contained in $\lambda k_{3}$ ). Only if $k_{2} \gg k_{3}$ so that $K i \rightarrow \lambda k_{3}$, is $K i$ independent of blood flow. Therefore in order to extract a parameter independent of blood flow (ligand transport) it is necessary to determine $K_{l} . \quad \lambda k_{3}$ can then be determined from $\mathrm{Eq}(13)$

$$
\lambda k_{3}=\frac{K_{1} K i}{K_{1}-K i}
$$

Wong et al. (1986a) have used a variation of the graphical analysis for the estimation of model parameters for the dopamine D2 ligand $\left[{ }^{11} \mathrm{C}\right]$ NMSP which appears to bind irreversibly over the time period of the experiment. In this modification the early part of the curve (before the linear phase) is used also to estimate parameters. The analysis equation uses the normalized time integral of plasma radioactivities, $\Theta$ given by

$$
\Theta=\int_{0}^{T} C p(t) d t / C p(T)
$$

and the tissue plasma ratio $(V(T))$

$$
V(T) \equiv \frac{C_{R O I}(T)}{C p(T)} \cong k_{3}\left[\frac{k_{2}}{k_{2}+k_{3}}\right] \frac{K_{1}^{R E F}}{k_{2}^{R E F}} \theta(T)+\frac{K_{1}^{R E F}}{k_{2}^{R E F}}(1+\rho)\left(\frac{k_{2}}{k_{2}+k_{3}}\right)^{2}\left(1-e^{-\theta(T) / \tau}\right)
$$

where $\rho=k_{5} / k_{6}$ accounts for a reversible component of either low specific or nonspecific binding in the receptor region. In the case of NMSP there are reference regions such as the cerebellum without specific binding from which $\lambda=\frac{K_{1}^{R E F}}{k_{2}^{R E F}}$ is determined (when $V(T)=C_{R E F}(T) / C p(T)$ ). The 
transition of $V(T)$ vs $\Theta(T)$ to a linear phase at later times is determined by $\tau$. When $\lambda$ is known the model has three parameters, $\mathrm{k}_{2}, \mathrm{k}_{3}$ and $\rho$. It is assumed that $\rho$ is not present in the reference region.

\section{Without plasma input}

When the concentration of original tracer in plasma reaches zero during the time of the study, $k_{3}$ may be estimated entirely from the shape of the time activity curve (TAC) (Frey et al. 1997a,b). This method was applied to estimation of acteylcholinesterase activity and was found to be suitable for regions of low enzyme activity (Koeppe et al. 1999).

Patlak and Blasberg (1985) extended the graphical analysis for irreversible ligands to an analysis using a reference region in place of the plasma input. It is assumed that the reference region has no specific binding so that in the steady state condition $\mathrm{C}_{\mathrm{REF}}(\mathrm{t}) \propto \mathrm{Cp}(\mathrm{t})$ for $t>t^{*}$. When this is true

$$
\frac{C_{R O I}\left(t_{i}\right)}{C_{R E F}\left(t_{i}\right)}=K^{\prime} \frac{\int_{0}^{t_{i}} C_{R E F}(t) d t}{C_{R E F}\left(t_{i}\right)}+b
$$

so that a plot of $C_{R O I}\left(t_{i}\right) / C_{R E F}\left(t_{i}\right)$ vs $\int_{0}^{t_{i}} C_{R E F}(t) d t / C_{R E F}\left(t_{i}\right)$ is a straight line for $\mathrm{t}_{\mathrm{i}}>\mathrm{t}^{*}$ with slope $K^{\prime}=K i /\left(D V_{R E F}+V p^{\prime}\right) \quad$ where $\mathrm{Vp}^{\prime}$ is the blood volume of the reference region and $\mathrm{DV}_{\mathrm{REF}}$ is the DV of the reference region.

\section{Limitations, reliability and other factors related to modeling image data \\ Sensitivity of the outcome measure}

The outcome measure must be sufficiently sensitive to variations in the underlying receptor availability to accurately register changes. This translates into particular requirements of tracer ligand kinetics. In the case of reversibly binding ligands, the binding potential $\left(k_{3} / k_{4}\right)$ needs to be sufficiently greater than one so that it can be reliably estimated. If it is too small there will be little difference between the reference region with no receptor concentration $\mathrm{DV}=K_{1} / k_{2}$ and the region with a receptor density $\mathrm{DV}=K_{1} / k_{2}\left(1+k_{3} / k_{4}\right)$. On the other hand if $\mathrm{BP}$ is too large, it may become difficult to obtain an estimate of the DV in the time span of the experiment. In particular, if $k_{3} \gg k_{2}$ either due to a high affinity $\left(k_{\text {on }}\right)$ or a large Bmax or slow tissue to plasma 
efflux, then the concentration of ligand bound to receptor is limited by tracer delivery, a situation referred to as "flow limited". This leads to an underestimation of the DV (or a large uncertainty in the DV) or if using an irreversible model, the receptor parameter $k_{3}$ is contaminated by delivery effects (see discussion in Koeppe et al. 1994). This has been a problem for some of the muscarinic cholinergic ligands such as scopolamine (Frey et al. 1992) and less of a problem although still present for $\left[{ }^{11} \mathrm{C}\right]$ tropanyl benzilate (Koeppe et al. 1994) and $\left[{ }^{11} \mathrm{C}\right]$ benztropine (Dewey et al. 1993a).

Figure 2 illustrates the sensitivity of the TAC of a simulated irreversible ligand to variations in the receptor binding parameter, $k_{3}$. Each curve from $k_{3}=.0033$ to 0.65 increases $k_{3}$ by $50 \%$ over the previous one $\left(K_{1}=.45 \mathrm{~mL} / \mathrm{min} / \mathrm{mL}, k_{2}=.075 \mathrm{~min}^{-1}\right)$. The bottom curve has no receptor binding $\left(k_{3}=0\right)$. For very small values of $k_{3}$, there is little change in the TAC with a relatively large change in $k_{3}$. The presence of even a small amount of noise would make it difficult to distinguish differences at this level. The maximum change occurs in the middle region. At the high end, when $k_{2}>k_{2}$ there is little change in the TAC with a large change in $k_{3}$ and the binding is "flow limited". (The flow limited condition can also be expressed in terms of Ki, (see Eq13)). When $K_{1} \sim K i$, only one parameter can be determined, $K_{1}$, and no information can be obtained about enzyme/receptor concentration.). In the regions of higher specific binding the estimates of $k_{3}$ become much more variable, although they are highly correlated to $k_{2}$ (Logan et al. 2000a; Koeppe et al. 1999). In order to reduce this variability, Fowler et al. (1995) have used the parameter $\lambda k_{3}$ which is much more stable since it contains the ratio $k_{3} / k_{2}$. Alternatively Koeppe et al. (1999) proposed using a scheme in which all three parameters are determined but the ratio $\lambda k_{3}$ is scaled to the value of $\lambda$ determined from a region of low specific binding thus giving a scaled value of $k_{3}$.

The sensitivity of irreversible ligands that are close to the flow limit can be improved by reducing the binding parameter, $k_{3}$. This was done with the tracer $\left[{ }^{11} \mathrm{C}\right] \mathrm{L}$-deprenyl by substituting deuterium for hydrogen at the reaction site. This is an example of the kinetic isotope effect in which the increased mass of the atom involved in the reaction slows the reaction rate. Figure 3 illustrates two uptake curves from $\left[{ }^{11} \mathrm{C}\right] \mathrm{L}$-deprenyl $\mathrm{H} 2$ and $\left[{ }^{11} \mathrm{C}\right] \mathrm{L}$-deprenyl-D2 in the same subject. The difference between $K_{1}$ and $K i$ is significantly greater for the $\mathrm{D} 2$ compound than for the $\mathrm{H} 2$ compound, 0.3 and $0.12\left(\mathrm{~mL} \mathrm{~min}^{-1} \mathrm{~mL}^{-1}\right)$ respectively. In other regions of interest with higher MAO B concentration the $\mathrm{H} 2$ difference was found to be even smaller. The 
sensitivity of $\mathrm{H} 2$ to differences in MAO B concentration is much less than for the D2 ligand. This leads to greater variability in model parameters.

\section{Which Model?}

The model structure that best describes a data set is not necessarily driven by the presence of multiple types of binding. For example, a ROI from a receptor containing region could be described by a one tissue compartment model even though there is specific binding to the receptor as well as nonspecific binding. Why the binding kinetics of one ligand requires a twocompartment model while the kinetics of another does not has to do with the impulse response function of the two-compartment model given by

$$
\begin{array}{ll}
\alpha_{1,2}=\left(\gamma \mp \sqrt{\gamma^{2}-4 k_{2} k_{4}}\right) / 2 & \gamma=k_{2}+k_{3}+k_{4} \\
A_{1}=\frac{K_{1}}{\alpha_{1}-\alpha_{2}}\left(k_{3}+k_{4}-\alpha_{1}\right) & A_{2}=\frac{K_{1}}{\alpha_{1}-\alpha_{2}}\left(\alpha_{2}-k_{3}-k_{4}\right)
\end{array}
$$

$A_{1} \exp \left(-\alpha_{1} t\right)+A_{2} \exp \left(-\alpha_{2} t\right)$ (Carson et al. 1998) where $\mathrm{A}_{1,2}$ and $\alpha_{1,2}$ are combinations of $K_{1}, k_{2}, k_{3}$ and $k_{4}$. If one of the exponential terms dominate, then a one compartment model will adequately describe the data. Following (Carson et al. 1998) whether a two compartment fit is required can be determined by considering the fraction of the area of the response function due to the second term for time $T$, that is

$$
\frac{A_{2}\left(1-\exp \left(-\alpha_{2} T\right)\right) / \alpha_{2}}{A_{1}\left(1-\exp \left(-\alpha_{1} T\right)\right) / \alpha_{1}+A_{2}\left(1-\exp \left(-\alpha_{2} T\right)\right) / \alpha_{2}}
$$

The effect of varying the binding parameters $k_{3}$ and $k_{4}$ (while maintaining a constant binding potential, $\mathrm{k}_{3} / \mathrm{k}_{4}$ ) on the integrated response function ratio of Eq 14 is shown in Figure 4. Using model parameters similar to those found for $\left[{ }^{11} \mathrm{C}\right]$ raclopride with $K_{1}=.15$ and $k_{2}=.36$ for all simulations giving $\mathrm{DV}=1.917\left(\mathrm{DV}_{1}\right.$ indicates the $\mathrm{DV}$ generated by fitting the data to a one tissue compartment model with two parameters, $\mathrm{DV}_{2}$ a two tissue model with four parameters). The maximum time was $60 \mathrm{~min} . \mathrm{DV}_{1}$ underestimates the true DV for the lower values of $k_{3}$ and $k_{4}$. This is improved somewhat by extending the analysis time to $95 \mathrm{~min}$ for which $\mathrm{DV}_{1}$ becomes 1.59 for $k_{3}=0.09$. The graphical DV's for the 4 cases were 1.80, 1.89, 1.92, 1.92. Extending the time to $95 \mathrm{~min}$ the $\mathrm{DV} V_{\mathrm{G}}$ was found to be 1.89 and 1.91 for $k_{3}=0.09$ and $0.18 \mathrm{~min}^{-1}$ respectively. 
There was no change in the other two. For the simulations with $k_{3}=0.09$ and 0.18 a two compartment model is required to recover the true DV using the NLLSQ method. For the two simulations with higher values of $k_{3}$ and $k_{4}, \mathrm{DV}_{1}$ is close to the true $\mathrm{DV}$ and the addition of another tissue compartment would not be justified since the parameters would most likely not be identifiable in the presence of noise.

There are also instances in which the "nonspecific" reference regions are better described by a two tissue compartment model. This has been observed for some studies with the radioligands $\left[{ }^{11} \mathrm{C}\right]$ raclopride (for example Logan, 2001b), and $\left[{ }^{18} \mathrm{~F}\right]$ spiperone (Logan et al.1987). Also AbiDargham et al. (2000) observed that a two compartment model gave a somewhat better fit to cerebellar data for the $\mathrm{D}_{1}$ ligand $\left[{ }^{11} \mathrm{C}\right] \mathrm{NNC} 112$. From 16 studies in the baboon with $\left[{ }^{11} \mathrm{C}\right]$ raclopride the $\mathrm{DV} V_{1}$ underestimated the $\mathrm{DV}$ compared to $\mathrm{DV} V_{2}$ and to $\mathrm{DV} \mathrm{G}_{\mathrm{G}}$, $\mathrm{DV}_{1} / \mathrm{DV}_{2}=.83 \pm .05$ and $\mathrm{DV}_{\mathrm{G}} / \mathrm{DV}_{2}=.98 \pm .02$ (Logan et al. 2001b). This appears not to be related to specific binding. This apparent additional binding could be due to an error in the metabolite correction of the input function. If the fraction of original tracer is small at later times, then a small error in the metabolite correction will result in a large difference in the plasma concentration (Carson et al. 1998). Also uptake of a small quantity of lipophilic metabolites at later times will result in a bias in the model. Whether the second compartment in these nonspecific regions is due to this or is in fact a true slow nonspecific binding is unclear. Also another issue is whether it is also present in the ROI under study and should be taken into account.

\section{Reference tissue methods}

Sossi et al. (2000) compared BP estimates from the graphical tissue input method and the simplified reference tissue method (SRTM) for 4 ligands, $\left[{ }^{11} \mathrm{C}\right]$ methylphenidate (DA transporter), $\left[{ }^{11} \mathrm{C}\right]$ dihydrotetrabenazine (DA vesicular transporter), $\left[{ }^{11} \mathrm{C}\right]$ raclopride (D2 antagonist) and $\left[{ }^{11} \mathrm{C}\right]$ Schering 23390 (D1 antagonist), finding nearly identical results for both methods and similar reliability and reproducibility. The BP estimates were somewhat lower than those from compartment analysis. BP from compartmental analysis were derived indirectly from the $\mathrm{DV}$ 's for the receptor and reference region so that $\mathrm{BP}=\left(\mathrm{DV} V_{\mathrm{ROI}}-\mathrm{DV} V_{\mathrm{REF}}\right) / \mathrm{DV} V_{\mathrm{REF}}$. The model used was the one tissue compartment model. Both the reference and receptor regions for these 
ligands could be described adequately by a one tissue compartment model satisfying the basic assumption of the simplified reference tissue method (SRTM).

Slifstein et al. (2000) compared the SRTM BP's with those from standard compartmental modeling using simulations with arterial input functions for the 5HT1A tracer $\left[{ }^{11} \mathrm{C}\right]$ WAY100635 and $\left[{ }^{11} \mathrm{C}\right] \mathrm{NNC1} 12$, a $\mathrm{D} 1$ receptor tracer. When the reference region was a single compartment the SRTM overestimated BP by 5 to $15 \%$. However, the assumption in the SRTM is that the receptor region can also be described with a single tissue compartment. The overestimate may be related to this. An additional compartment in the the reference region also distorted the results as one would expect with the SRTM underestimating the $B P$, also differences in flow between the two regions affected the $B P$. There is the additional complication that the receptor region may also contain the slow nonspecific binding.

Alpert et al. (2000) also tested the SRTM with simulations using a two tissue compartment model and a measured input function with labeled altropane, a dopamine transporter ligand. The reference region was generated with a single tissue compartment model. For the receptor ROI $K_{1}=.38 \mathrm{k}_{2}=.15$ and BP was fixed but values of $k_{3}$ and $k_{4}$ were allowed to vary. For lower values of $k_{3}<.5$ min-1 there was deviation from the true $B P$ which became larger as $\mathrm{k}_{3}$ decreased. A likely explanation for this behavior is that for the larger values of $k_{3}$ and $k_{4}$, a single compartment would describe the data but as $k_{3}$ deceases, a two compartment model is required which violates the basic assumption of the SRTM.

In order to address one of the limitations of the SRTM, Watabe et al. (2000) have proposed a two tissue compartment model to use for the reference region while retaining the one tissue compartment for the ROI .

An alternative reference tissue model is used by Acton et al. (1999) for describing $\left[{ }^{99 \mathrm{~m}}\right.$ Tc]TRODAT-1 binding to DA transporters in baboons using SPECT. The assumptions made were that the transport constants were the same in both the ROI and reference region and that the specific binding component could be extracted by subtracting the reference region from the ROI as in Farde's pseudoequilibrium method. The constraint of having the same transport parameters for both regions is not likely to be valid for all ligands limiting the usefulness of this technique. The reference region method was lower than the BP derived using the compartment model but the same constraint was used in the model. Also it is unlikely that the specifically bound is 
accurately represented by the difference between the ROI and reference region over the time course of the study. (Logan, et al. 1997).

\section{Bias in the Graphical Analysis Method}

The graphical analysis method is a useful tool for rapidly obtaining information about the binding of radioligands. The strength of the method is that it does not require a particular model structure. However, since it is derived from the linearized compartmental equations, it also displays a bias in the case of noisy data resulting in the underestimation of the slope (DV) and the underestimation is greater with larger DV's (Hsu et al. 1997; Slifstein et al. 1999; AbiDargham et al. 2000). In order to remove the bias, Logan et al. (2001a) have proposed a modification of the GLLS method developed by Feng et al. (1993) to use as a smoothing technique for more general classes of model structures. The one compartment GLLS method was applied to the data in two parts, that is one set of parameters was determined for times 0 to $T_{1}$ and a second set from $T_{1}$ to the end time. The curve generated from these two sets of parameters was then used as input to the graphical method. This was been tested using simulations of data similar to that of the PET ligand $\left[{ }^{11} \mathrm{C}\right]-d$-threo-methylphenidate (MP, $\mathrm{DV}=35 . \mathrm{mL} / \mathrm{mL})$ and $\left[{ }^{11} \mathrm{C}\right]$ raclopride $(\mathrm{RAC}, \mathrm{DV}=1.92 \mathrm{~mL} / \mathrm{mL})$ with the result that in the case of moderate noise the bias was substantially removed. This combination of the GLLS method and the graphical method provides the possibility of retaining the model independent type of analysis without the bias inherent in the linear methods while still maintaining a fairly simple method of analysis. This method was also applied to the simplified reference tissue model of Lammertsma and Hume (1996). The equation was modified to allow a linear solution for $k_{2}$ as in Feng's method. Estimates of three parameters were generated in this case as opposed to two when the input function is measured. The same two part procedure was used to smooth the data as was done with the DV and the graphical method was applied to the smoothed data using the reference region and an average efflux constant (Logan et al. 1996).

\section{Construction of Parametric Images}

Reliable image wide parameter estimation methods are important because of the potential increased information content of parametric images over ROI analysis, although both are important. One desirable characteristic of image wide parameter estimation methods is that they 
perform well in the presence of noise which is considerably greater than in ROIs. Other desirable characteristics include speed of the calculation since it must be done for all voxels in the image, and model independence of the method since there will generally be variations in specific binding so that voxels in one structure may require a different model from voxels in another structure. The weighted least squares method (Alpert et al. 1984; Koeppe et al. 1991) works well when a one compartment model is adequate for all regions. From this method parametric images of ligand transport rate and distribution volume can be constructed. It requires a measured input function. Holthoff et al. (1991) have shown that altering blood flow does not alter the DV and thus demonstrated that the DV obtained in this manner is a measure of specific binding and not ligand transport.

Graphical analysis with a measured plasma input function (Logan et al. 1990) is model independent but gives a biased estimate in the presence of significant noise particularly for ligands with high DV's. However, Koeppe et al. (1997) found good agreement between images generated using the weighted least squares and graphical methods for $(+)-\alpha-\left[{ }^{11} \mathrm{C}\right]-$ dihydrotetrabenazine (DTBZ) which binds to the vesicular monoamine transporter (DV in the caudate-putamen was $\sim 11$ to $12 \mathrm{~mL} / \mathrm{mL}$ ). The smoothing strategy discussed previously may prove to be a means of maintaining the model independence.

The method of Gunn et al. (1997) is a modification of the simplified reference tissue model adapted to parametric image construction without a measured plasma input function. The method uses precalculated basis functions for a range of values of the nonlinear model parameter and includes parameter bounds. The assumptions are the same as in the original formulation of the method, that both the reference region and binding regions can be described by a one tissue compartment model (Lammertsma and Hume 1996). The method was found to work well for $\left[{ }^{11} \mathrm{C}\right]$ raclopride and $\left[{ }^{11} \mathrm{C}\right] \mathrm{CFT}$. The presence of additional binding in the reference region was tested by simulations and found to underestimate the BP as expected. The graphical method with a reference region input (Logan et al. 1996) is model independent but is subject to bias in the presence of noise. The previously described adaptation of the simplified reference tissue method used as a smoothing technique prior to applying the graphical analysis has been proposed as a possible solution to the bias problem.

The nonlinear least squares methods which are based on a particular model structure generally require considerable computation time as well as being subject to local minima. These methods 
are not generally used for image wide parameter estimation of DV or BP. The simplicity of the bolus plus constant infusion equilibrium method makes it an attractive alternative although different structures may require different infusion schedules to achieve equilibrium. In this case the method could be used for estimation of BP in voxels within a given structure.

For irreversible ligands parametric images of the influx constant $\mathrm{Ki}$ can easily be constructed (Patlkak et al. 1983, 1985). However, since Ki depends upon blood flow comparisons based on this parameter will be subject to differences in blood flow as well as changes in receptor binding. If changes in transport are known to be important, then the transport constant needs to be estimated. Logan et al (2000b) have proposed a method for estimating $\mathrm{K}_{1}$ from initial part of uptake curve and using $\mathrm{Ki}$ to estimate $\lambda \mathrm{k}_{3}$.

Turkheimer et al. (2000) has introduced a new approach to generating parameteric images that is based on a wavelet transform of each image in a dynamic sequence. Linear modeling procedures such as the graphical analyses can be done on the wavelet coefficients which represent a spatial object as opposed to a single pixel. This is followed by thresholding and the application of the inverse wavelet transform to recover the parametric image. Among the examples presented were dynamic PET FDG and $\left[{ }^{11} \mathrm{C}\right]$ raclopride studies with the result that noise was reduced compared to graphical analyses without the wavelet transform while details of brain structures were preserved.

\section{Summary}

A description of some of the methods used in neuroreceptor imaging to distinguish changes in receptor availability has been presented in this chapter. It is necessary to look beyond regional uptake of the tracer since uptake generally is affected by factors other than the number of receptors for which the tracer has affinity. An exception is the infusion method producing an equilibrium state. The techniques vary in complexity some requiring arterial blood measurements of unmetabolized tracer and multiple time uptake data. Others require only a few plasma and uptake measurements and those based on a reference region require no plasma measurements. We have outlined some of the limitations of the different methods. Laruelle (1999) has pointed out that test/retest studies to which various methods can be applied are crucial in determining the optimal method for a particular study. The choice of method will also depend upon the application. In a clinical setting, methods not involving arterial blood sampling are 
generally preferred. In the future techniques for externally measuring arterial plasma radioactivity with only a few blood samples for metabolite correction will extend the modeling options of clinical PET. Also since parametric images can provide information beyond that of ROI analysis, improved techniques for generating such images will be important., particularly for ligands requiring more than a one-compartment model. Techniques such as the wavelet transform proposed by Turkheimer et al. (2000) may prove to be important in reducing noise and improving quantitation.

\section{Acknowledgments}

This research was carried out at Brookhaven National Laboratory under contract DE-AC02$98 \mathrm{CH} 10886$ and with the U. S. Department of Energy and supported by its Office of Biological and Environmental Research and by the National Institutes of Health, National Institute of Neurological Diseases and Stroke (NS 15380). 


\section{Figure Captions:}

Figure 1: Simulated data comparing two ligands with the same DV (DV=60 mL/mL) but different kinetics. The uptake is illustrated in a. The upper curve ( $)$ has $\mathrm{K}_{1}=0.5$ $\mathrm{mL} / \mathrm{min} / \mathrm{mL}$ and $\lambda=10 . \mathrm{mL} / \mathrm{mL}$ with $\mathrm{k}_{3}=0.1 \mathrm{~min}^{-1}$ and $\mathrm{k}_{4}=.02 \mathrm{~min}^{-1}\left(\mathrm{k}_{3} / \mathrm{k}_{4}=5\right)$. The lower curve $(\diamond)$ has $\mathrm{K}_{1}=.6, \lambda=3, \mathrm{k}_{3}=.1$ and $\mathrm{k}_{4}=.005\left(\mathrm{k}_{3} / \mathrm{k}_{4}=20\right)$. The graphical analysis is illustrated in $\mathbf{b}, \mathbf{t}^{*}=35 \mathrm{~min}$ for $(\diamond)$ and $80 \mathrm{~min}$ for $(\diamond)$.

Figure 2: Sensitivity of the time activity curve of a simulated irreversible ligand to variations in the receptor binding parameter, $\mathrm{k}_{3}$. Each curve from $\mathrm{k}_{3}=.0033$ to .65 increases $\mathrm{k}_{3}$ by $50 \%$ over the previous one $\left(K_{1}=.45 \mathrm{~mL} / \mathrm{min} / \mathrm{mL}, k_{2}=.075 \mathrm{~min}^{-1}\right)$. The bottom curve has no receptor binding $\left(k_{3}=0\right)$.

Figure 3: Time activity curves from $\left[{ }^{11} \mathrm{C}\right] \mathrm{L}$-deprenyl H2 $(\diamond)$ and $\left[{ }^{11} \mathrm{C}\right] \mathrm{L}$-deprenylD2 $(\diamond)$ in the same subject.

Figure 4: The effect of varying the binding parameters $\mathrm{k}_{3}$ and $\mathrm{k}_{4}$ (while maintaining a constant binding potential, $\mathrm{k}_{3} / \mathrm{k}_{4}$ ) on the integrated response function ratio of Eq 14. R2 is the numerator in $\mathrm{Eq}(14)$ and $\mathrm{R} 1+\mathrm{R} 2$ is the denominator. Values of the kinetic constants are indicated. $\mathrm{DV}_{1}$ is the DV determined from a one compartment model fit using $60 \mathrm{~min}$ of uptake data. The true DV was $1.92 \mathrm{~mL} / \mathrm{mL}$. 
Abi-Dargham A, Martinez D, Mawlawi O, Simpson N, Hwang D, Slifstein M, Anjilvel S, PidcockJ J, Guo N, Lombardo I, Mann J, VanHeertum R, Foged C, Halldin C and Laruelle M (2000). Measurement of striatal and extrastriatal dopamine D1 receptor binding potential with $\left[{ }^{11} \mathrm{C}\right] \mathrm{NNC} 112$ in humans: validation and reproducibility. Journal of Cerebral Blood Flow and Metabolism, 20, 225-243.

Acton PD, Kushner SA, Kung M-P, Mozley PD, Ploss1 K, Kung HF (1999). Simplified reference region model for the kinetic analysis of [99mTc]TRODAT-1 binding to dopamine transporters in nonhuman primates using single-photon emission tomography. European Journal of Nuclear Medicine, 26, 518-526.

Alpert N, Bonab A, Fischman A (2000). The simplified reference region model for parametric imaging: Domain of validity. Journal of Nuclear Medicine, 41, 57P.

Alpert NM, Eriksson L, Chang JY, M. B, E. LJ, Correia JA, Bohm C, H. AR, Taveras JM (1984). Strategy for the measurement of regional cerebral blood flow using shortlived tracers and emission tomography. Journal of Cerebral Blood Flow and Metabolism, 4, 28-34.

Blasberg RG, Patlak CS, Fenstermacher JD (1979). Meaurement of blood-brain transfer constants for three nonmetabolized amino acids. International Society of Neurochemistry, 7, 238.

Blomqvist $\mathrm{G}$ (1984). On the construction of functional maps in positron emission tomography. Journal of Cerebral Blood Flow and Metabolism, 4, 629-632.

Bremner JD, Horti A, Staib LH, Zea_once Y, Soufer R, Charney DS and Baldwin R (2000) Kinetic modeling of benzodiazepine receptor binding with PET amd high specific activity [ $\left.{ }^{11} \mathrm{C}\right]$ Iomazenil in healthy human subjects. Synapse 35, 68-77.

Carson RE (1986). Parameter estimation in positron emission tomography. In M. Phelps, J. Mazziotta, \& H. Schelbert (Eds.), Positron emission tomography and autoradiography: Principles and applications for the brain and heart (pp. 347390). New York: Raven Press.

Carson RE, Breier A, de Bartolomeis A, Saunders RC, Su TP, Schmall B, Der MG, Pickar D, Eckelman WC (1997). Quantification of amphetamine-induced changes in $\left[{ }^{11} \mathrm{C}\right]$ raclopride binding with continuous infusion. Journal of Cerebral Blood Flow and Metabolism, 17, 437-47.

Carson RE, Channing MA, Blasberg RG, Dunn BB, Cohen RM, Rice KC, Herscovitch P (1993). Comparison of Bolus and infusion methods for receptor quantitation: Application to $\left[{ }^{18} \mathrm{~F}\right]$ cyclofoxy and positron emission tomography. Journal of Cerebral Blood Flow and Metabolism, 13, 24-42.

Carson RE, Kiesewetter DO, Jagoda E, Der MG, Herscovitch P, Eckelman WC (1998). Muscarinic cholinergic receptor measurements with [18F]FP-TZTP: control and competition studies. Journal of Cerebral Blood Flow and Metabolism, 18, 113042.

Crone C (1963). Permeability of capillaries in various organs as determined by the use of the indicator diffusion method. Acta Physiol Scand, 58, 292-305.

Dewey SL, Brodie JD, Fowler JS, MacGregor RR, Schlyer DJ, King PT, Alexoff DL, Volkow ND, Shiue C-Y, Eolf AP, Bendriem B (1990) Positron emission 
tomography (PET) studies of dopaminergic/cholinergic interactions in the baboon brain. Synapse 6:321-327.

Dewey SL, Smith GS, Logan J, Brodie JD (1993a). Modulation of central cholinergic activity by GABA and serotonin: PET studies with $\left[{ }^{11} \mathrm{C}\right]$-benztropine in primates. Neuropsychopharmacology, 8, 371-376.

Dewey SL, Smith GS, Logan J, Brodie JD, Fowler JS, Wolf AP (1993b). Striatal binding of the PET ligand $\left[{ }^{11} \mathrm{C}\right.$ ] raclopride is altered by drugs that modify synaptic dopamine levels. Synapse, 13, 350-356.

Ding YS, Fowler JS, Volkow ND, Dewey SL, Wang G-J, Logan J, J. GS, Pappas N (1997). Chiral drugs: comparison of the pharmacokinetics of $\left[{ }^{11} \mathrm{C}\right] \mathrm{d}$-threo and Lthreo-methylphenidate in the human and baboon brain. Psychopharmacology, 131, 71-78.

Ding YS, Fowler JS, Volkow ND, Gatley SJ, Logan J, Dewey SL, Alexoff D, Fazzini E, Wolf AP (1994). Pharmacokinetics and in vivo specificity of $\left[{ }^{11} \mathrm{C}\right] \mathrm{d} 1$-threomethylphenidate for the presynaptic dopaminergic neuron. Synapse, 18, 152-160.

Endres CJ and Carson RE (1998) Assessment of dynamic neurotransmitter changes with bolus or infusion delivery of neuroreceptor ligands Journal of Cerebral Blood Flow and Metabolism 18, 1196-1210.

Evans AC (1987). A double integral form of the three-compartment model, four rateconstant model for faster generation of parameter maps. Journal of Cerebral Blood Flow and Metabolism, 7 (suppl 1), S453.

Farde L, Hall H, Ehrin E, Sedvall G (1986). Quantitative analysis of D2 dopamine receptor binding in the living human brain by PET. Science, 231, 258-261.

Farde L, Halldin C, Stone-Elander S and Sedvall G (1987) PET analysis of human dopamine receptor subtypes using $\left[{ }^{11} \mathrm{C}\right]-\mathrm{SCH} 23390$ and $\left[{ }^{11} \mathrm{C}\right]$ raclopride. Psychopharmacology 92, 278-284.

Farde L, Eriksson L, Blomquist G, Halldin C (1989). Kinetic analysis of central $\left[{ }^{11} \mathrm{C}\right]$ raclopride binding to D2-dopamine receptors studied by PET- a comparison to the equilibrium analysis. Journal of Cerebral Blood Flow and Metabolism, 9 , 696-708.

Farde L, Swahn CG, Pike VW, Halldin C (1998). Quantitative analyses of carbonylcarbon-11-WAY-100635 binding to central 5-hydroxytryptamine-1A receptors in - man. Journal of Nuclear Medicine, 39, 1965-1971.

Feng D, Wang Z, Huang S-C (1993). A study on statistically reliable and computationally efficient algorithms for the measurement of local cerebral blood flow with positron emission tomography. IEEE Trans Medical Imaging, 12, 182-188.

Feng D, Huang S-C, Wang Z, Ho D (1996). an unbiased parametric imaging algorithm for nonuniformly sampled biomedical system parameter estimation. IEEE Trans Medical Imaging, 15, 512-518.

Fowler JS, MacGregor RR, Wolf AP, Arnett CD, Dewey SL, Schlyer D, Christman D, Logan J, Smith M, Sachs H (1987). Mapping human brain monoamine oxide A and $B$ with ${ }^{11} \mathrm{C}$ labeled suicide inactivators and PET. Science, 235, 481-485.

Fowler JS, Volkow ND, Wolf AP, Dewey SL, Schlyer DJ, R. MR, R. H, Logan J, Bendriem B, Gatley SJ and Christman D (1989). Mapping cocaine binding sites in human and baboon brain in vivo. Synapse, 4, 371-377. 
Fowler JS, Wang G-J, Logan J, Xie S, Volkow ND, MacGregor RR, Schlyer DJ, Pappas N, Alexoff DL, Patlak C, Wolf AP (1995). Selective reduction of radiotracer trapping by deuterium substitution: Comparison of carbon-11-L-deprenyl and carbon-11-deprenyl-D2 for MAO B mapping. Journal of Nuclear Medicine, 36, 1255-1262.

Frey KA, Koeppe RA, Kilbourn MR, Snyder SE, Kuhl DE (1997a). PET quantification of cortical acetylcholinesterase inhibition in monkey and human. Journal of Nuclear Medicine, 38, 146P.

Frey KA, Koeppe RA, Kilbourn MR, Snyder SE, Schwarz R, Callahan MJ (1997b). PET quantification of acetylcholinesterase activity in monkey brain without blood sampling: methodology and effect of THA. Journal of Cerebral Blood Flow and Metabolism, 17, S328.

Frey KA, Koeppe RA, Mulholland GK, Jewett D, Hichwa R, Ehrenkaufer RL, Carey JE, Wieland DM, Kuhl DE, Agranoff BW (1992). In vivo muscarinic cholinergic receptor imaging in human brain with $\left[{ }^{11} \mathrm{C}\right]$ scopolamine and positron emission tomography. Journal of Cerebral Blood Flow and Metabolism, 12, 147-154.

Frost JJ, Douglass KH, Mayberg HS, Dannals RF, Links JM, Wilson AA, Ravert HT, Crozier WC, Wagner HNJ (1989). Multicompartmental analysis of [ $\left.{ }^{11} \mathrm{C}\right]-$ Carfentanil binding to opiate receptors in humans measured by positron emission tomography. Journal of Cerebral Blood Flow and Metabolism, 9, 398-409.

Fujita M, Seibyl JP, VerHoeff NP, Ichise M, Baldwin RM, Zoghbi SS, Burger C, Staley JK, Rajeevan N, Charney DS, Innis RB (1999). Kinetic and equilibrium analyses of [123I]epidepride binding to striatal and extrastriatal dopamine D2 receptors. Synapse, 34, 290-304.

Gjedde A (1981). High and low affinity transport of D-glucose from blood to brain. Journal of Neurochemistry, 36, 1463-1471.

Gunn RN, Lammertsma AA, Hume SP, Cunningham VJ (1997). Parametric imaging of ligand-receptor binding in PET using a simplified reference region model. Neuroimage, 6, 279-287.

Hietala J, Nagren K, Lehikoinen P, Ruotsalainen U, Syvalahti E (1999). Measurement of striatal D2 dopamine receptor density and affinity with $\left[{ }^{11} \mathrm{C}\right]$-raclopride in vivo: A test-retest analysis. Journal of Cerebral Blood Flow and Metabolism 19, 210 217.

Holthoff VA, Koeppe RA, Frey KA, Paradise AH, Kuhl DE (1991). Differentiation of radioligand delivery and binding in the brain: Validation of a two compartment model for $\left[{ }^{11} \mathrm{C}\right]$ flumazenil. Journal of Cerebral Blood Flow and Metabolism, 11, 745-752.

Hsu H, Alpert N, Christian B, Bonab A, Morris E, Fishman A (1997). Noise properties of a graphical assay of receptor binding. Journal of Nuclear Medicine, 38, $204 \mathrm{P}$.

Ichise M Ballinger JR (1996). From graphical analysis to multilinear regression analysis of reversible radioligand binding. Journal of Cerebral Blood Flow and Metabolism, 16, 750-752.

Ichise M, Fujita M, Seibyl JP, Verhoeff NPLG, Baldwin RM, Zoghbi SS, Rajeevan N, Charney DS, Innis RB (1999). Graphical Analysis and simplified quantification of striatal and extrastriatal dopamine D2 receptor binding with [123I]epidepride SPECT. Journal of Nuclear Medicine, 40, 1902-1912. 
Inoue O, Tsukada H, Yonezawa H, Suhara T, Langstrom B (1991) Reserpine-induced reduction of in vivo binding of SCH 23390 and $\mathrm{N}$-methylspiperone and its reversal by D-amphetamine. European Journal of Pharmacology, 197, 143-149.

Inoue O, Wakahara S, Kobayashi K, Gee A (1999a) Enhancement pf 3H-Nmethylspiperone binding but not $3 \mathrm{H}$-raclopride binding in mouse striatum by MK801: evidence that factors other than competition by endogenous dopamine are responsible for changes in D2 receptor binding in vivo. Journal of Neural Transmission, 106, 131-137.

Inoue O, Kobayashi K, Hosoi R, Yamaguchi M, Gee A (1999b) Discrepancies in apparent dopamine D2 receptor occupancy between $3 \mathrm{H}$-raclopride and $3 \mathrm{H}-\mathrm{N}$ methylspiperone Journal of Neural Transmission, 106, 1099-1104.

Innis RB, Malison RT, Al-Tikriti M, Hoffer PB, Sybirska EH, Seibyl JP, Zoghbi SS, Baldwin RM, Laruelle MA, Smith E, Charney DS, Heninger G, Elsworth JD, Roth RH(1992). Amphetamine-stimulated dopamine release competes in vivo for [123I]IBZM binding to the D2 receptor in non-human primates. Synapse, 10, $177-$ 184

Kety S (1951) The theory and and application of the exchange of inert gases at the lung and tissues Pharmacological Review, 3, 1-41.

Kiesewetter DO, Carson RE, Jagoda EM, Herscovitch P, Eckelman WC (1999). In vivo muscarinic binding of 3-(alkylthio)-3-thiadiazolyl tetrahydropyridines. Synapse, 31, 29-40.

Koeppe RA, Frey KA, Mulholland GK, Kilbourn MR, Buck A, Lee KS, Kuhl DE (1994). $\left[{ }^{11} \mathrm{C}\right]$ tropanyl benzilate binding to muscarinic cholinergic receptors: methodology and kinetic modeling alternatives. Journal of Cerebral Blood Flow and Metabolism, 14, 85-99.

Koeppe RA, Frey KA, Kume A, Albin R, Kilbourn MR, Kuhl DE (1997) Equilibrium versus compartmental analysis for assessment of the vesicular monoamine transporter using $(+)$-alpha- $\left[{ }^{11} \mathrm{C}\right]$ dihydrotetrabenazine (DTBZ) and positron emission tomography. Journal of Cerebral Blood Flow and Metabolism, 17, 919931.

Koeppe RA, Frey KA, Snyder SE, Meyer P, Kilbourn MR, Kuhl DE (1999). Kinetic modeling of $\mathrm{N}-\left[{ }^{11} \mathrm{C}\right]$ methylpiperidin-4-yl propionate: Alternatives for analysis of an irreversible positron emission tomography tracer for measurement of acetylcholinesterase activity in human brain. Journal of Cerebral Blood Flow and Metabolism, 19, 1150-1163.

Koeppe RA, Holthoff VA, Frey KA, Kilbourn MR, Kuhl DE (1991). Compartmental analysis of $\left[{ }^{11} \mathrm{C}\right]$ flumazenil kinetics for the estimation of ligand transport rate and receptor distribution using positron emission tomography. Journal of Cerebral Blood Flow and Metabolism, 11, 735-44.

Lammertsma A, Bench C, Hume S, Osman S, Gunn K, Brooks D, Frackowiak R (1996). Comparison of methods for analysis of clinical $\left[{ }^{11} \mathrm{C}\right]$ raclopride studies. Journal of Cerebral Blood Flow and Metabolism, 16, 42-52.

Lammertsma A Hume S (1996). Simplified reference tissue model for PET receptor studies. Neuroimage, 4, 153-158.

Laruelle M (1999). Modelling: when and why? European Journal of Nuclear Medicine, 26, 571-572. 
Laruelle M (2000). Imaging synaptic neurotransmission with in vivo binding competition techniques: A critical review. Journal of Cerebral Blood Flow and Metabolism, 20, 423-451.

Laruelle M, Iyer RN, Al-Tikriti S, Zea-Ponce Y, Malison R, Zoghbi SS, Baldwin RM, Kung HF, Charney DS, Hoffer PB, Innis RB, Bradbury CW (1997). Microdialysis and SPECT measurements of amphetamine- induced dopamine release in nonhuman primates. Synapse, 25, 1-14.

Lassen NA Perl W (1979). Tracer kinetic methods in medical physiology. New York: Raven Press.

Logan J, Fowler J, Volkow N, Wang G-J, Ding Y, Alexoff D (1996). Distribution volume ratios without blood sampling from graphical analysis of PET data. Journal of Cerebral Blood Flow and Metabolism, 16, 834-840.

Logan J, Fowler J, Volkow N, Wolf A, Dewey S, Schlyer D, Macgregor R, Hitzmann R, Bendriem B, Gatley S, Christman D (1990). Graphical analysis of reversible radioligand binding from time-activity measurements applied to $\left[\mathrm{N}^{1}{ }^{11} \mathrm{C}\right.$-methyl](-)-cocaine PET studies in human subjects. Journal of Cerebral Blood Flow and Metabolism, 10, 740-747.

Logan J, Dewey SL, Wolf AP, Fowler JS, Brodie JD, Angrist B, Volkow ND and Gatley SJ (1991) Effects of endogenous dopamine on measures of [18F]Nmethylspiroperidol binding in the basal ganglia: comparison of simulations and experimental results from PET studies in Baboons Synapse, 9, 195-207.

Logan J, Volkow ND, Fowler JS, Wang GJ, Fischman MW, Foltin RW, Abumrad NN, Vitkun S, Gatley SJ, Pappas N, Hitzemann R, Shea CE (1997). Concentration and occupancy of dopamine transporters in cocaine abusers with $\left[{ }^{11} \mathrm{C}\right]$ cocaine and PET. Synapse, 27, 347-56.

Logan J, Fowler JS, Volkow ND, Wang G-J, MacGregor RR, Shea C (2000a). reproducibility of repeated measures of deuterium substituted $\left[{ }^{11} \mathrm{C}\right] \mathrm{L}$-deprenyl $\left({ }^{11} \mathrm{C}\right] \mathrm{L}$-deprenyl-D2) binding in the human brain. Nuclear Medicine and Biology, 27, 43-49.

Logan J (2000b). Graphical Analysis of PET Data Applied to Reversible and Irreversible Tracers. Nuclear Medicine and Biology, in press.

Logan J, Fowler JS, Volkow ND, Ding Y-S, Wang G-J and Alexoff DL (2001a) A strategy for removing the bias in the graphical analysis method. Journal of Cerebral Blood Flow and Metabolism, in press.

Logan J, Schiffer W, Dewey SL (2001b) unpublished data.

Mathis CA, Simpson NR, Mahmood K, Kinahan PE, Mintun MA (1994). [ ${ }^{11}$ C]WAY 100635: a radioligand for imagining 5-HT1A receptors with positron emission tomography. Life Science, 55, PL403-407.

Mintun MA, Raichle ME, Kilbourn MR, Wooten FG, Welch MJ (1984). A quantitative model for the in vivo assessment of drub binding sites with positron emission tomography. Annals of Neurology, 15, 217-227.

Patlak CS and Fenstermacher JD (1975) Measurements of dog blood-brain transfer constants by ventriculocisternal perfusion American Journal of Physiology, 229, 877-884.

Patlak CS and Pettigrew KD (1976) A method to obtain infusion schedules for prescribed blood concentration time courses. Journal of Applied Physiology, 10, 458-463. 
Patlak CS Blasberg RG, FenstermacherJD (1983) Graphical evaluation of blood-to-brain transfer constants from multiple-time uptake data. Journal of Cerebral Blood Flow and Metabolism, 3, 1-7.

Patlak CS Blasberg RG (1985). Graphical evaluation of blood-to-brain transfer constants from multiple-time uptake data. Generalizations. Journal of Cerebral Blood Flow and Metabolism, 5, 584-590.

Price JC, Mayberg HS, Dannals RF, Wilson AA, Ravert HT, Sadzot B, Rattner Z, Kimball A, Feldman MA and Frost JJ (1993) Measurement of benzodiazepine receptor number and affinity in humans using tracer kinetic modeling, positron emission tomography and $\left[{ }^{11} \mathrm{C}\right]$ flumazenil. Journal of Cerebral Blood Flow and Metabolism, 13, 656-667.

Renkin EM (1959) Transport of potassium-42 from blood to tissue in isolated mammalian skeletal muscles. American Journal of Physiology, 197, 1205-1210.

Seeman P, Niznik HB, and Guan HC (1990) Elevation of dopamine D2 receptors in schizophrenia is underestimated by radioactive raclopride. Archives of General Psychiatry, 47, 1170-1172.

Sawada Y, Kawai R, McManaway M, Otsuki H, Rice KC, Patlak CSand Blasberg RG (1991) Kinetic analysis of transport and opoid receptor binding of [3H](-)cyclofoxy in rat brain in vivo: Implications for human studies. Journal of Cerebral Blood Flow and Metabolism, 11, 183-203.

Slifstein M and Laruelle M (1999) Statistical bias in the Logan graphical method. Journal of Nuclear Medicine, 40, 35P.

Slifstein M, Parsey R, Mann J and Laruelle M (2000) Derivation of Neuroreceptor Binding Parameters with the simplified reference tissue model: Effect of model assumptions violations. Journal of Nuclear Medicine, 41, 57P.

Sossi V, Holden JE, Chan G, Krywinski M, Stoessl AJ, Ruth TJ (2000). Analysis of four dopaminergic tracer kinetics using two different tissue input function methods. Journal of Cerebral Blood Flow and Metabolism, 20, 653-660.

Suhara T, Fukuda H, Inoue O, Suzuki K, Yamasaki T and Tateno Y (1991) Age-related changes in human D1 receptors measured by positron emission tomography Psychopharmacology 103, 43-45.

Thie JA, Smith GT and Hubner KF (1997) Linear least squares compartment-model independent parameter identification in PET. IEEE Transactions on Medical Imaging, 16, 11-16.

Turkheimer FE, Banati RB, Visvikis D, Aston JAD, Gunn RN and Cunningham VJ (2000) Modeling dynamic PET -SPECT studies in the wavelet domain. Journal of Cerebral Blood Flow and Metabolism, 20, 1610-1618.

Volkow N, Ding Y, Fowler J, Wang G-J, Logan J, Gatley S, Schlyer D and Pappas N (1995) A new PET ligand for the dopamine transporter: Studies in the human brain. Journal of Nuclear Medicine, 36, 2162-2168.

Volkow N, Fowler J, Wang G-J, Dewey S, Schlyer D, MacGregor R, Logan J, Alexoff D, Shea C, Hitzemann R, Angrist B, Wolf A (1993). Reproducibility of repeated measures of carbon-11-raclopride binding in the human brain. Journal of Nuclear Medicine, 34, 609-613.

Volkow ND, Wang G-J, Fowler JS, Logan J, Schlyer D, R. H, Lieberman J, Angrist B, Pappas N, MacGregor R, Burr G, Cooper T and Wolf AP (1994). Imaging 
endogenous dopamine competition with $\left[{ }^{11} \mathrm{C}\right]$ raclopride in the human brain. Synapse, 16, 255-262.

Watabe H, Endres CJ, Breier A, Schmall B, Eckelman WC, and Carson RE (2000) Measurement of dopamine release with continuous infusion of $\left[{ }^{11} \mathrm{C}\right]$ raclopride: optimization and signal-to-noise considerations. Journal of Nuclear Medicine, 41, 522-30.

Wong DF, Gjedde A and Wagner HN, Jr. (1986a) Quantification of neuroreceptors in the living human brain. I. Irreversible binding of ligands. Journal of Cerebral Blood Flow and Metabolism, 6, 137-146

Wong DF, Gjedde A, Wagner Henry N. J, Dannals RF, Douglass KH, Links JM and Kuhar MJ (1986b) Quantification of neuroreceptors in the living human brain. II. Inhibition studies of receptor density and affinity. Journal of Cerebral Blood Flow and Metabolism, 6, 147-153.

Zawarynski P, Tallerico T, Seeman P, Lee SP, O'Dowd BF, George SR (1998) Dopamine D2 receptor dimers in human and rat brain FEBS Letters, 441, 383386.

Zubieta J-K, Koeppe RA, Mulholland GK, Kuhl DE and Frey KA (1998) Quantification of muscarinic cholinergic receptors with $\left[{ }^{11} \mathrm{C}\right] \mathrm{NMPB}$ and positron emission tomography: Method development and differentiation of tracer delivery from receptor binding. Journal of Cerebral Blood Flow and Metabolism, 18, 619-631. 


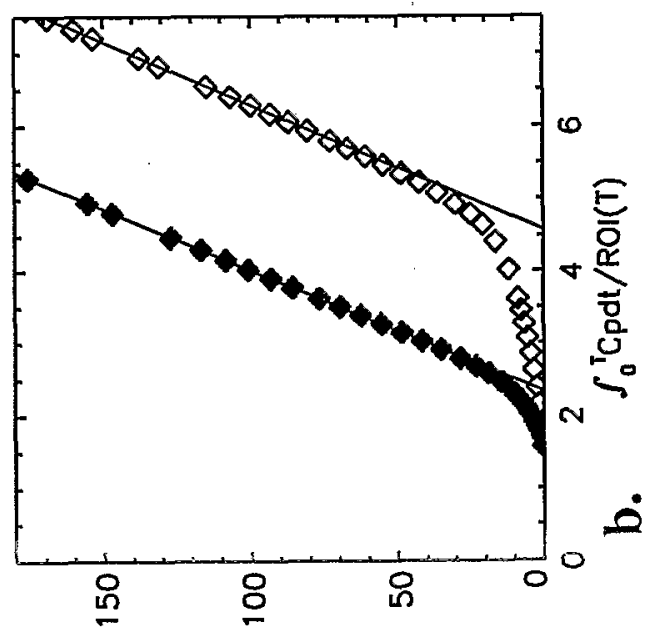

(1) $10 \mathrm{OH} / \mathrm{PPIOH}_{1}{ }^{\circ} \mathrm{S}$

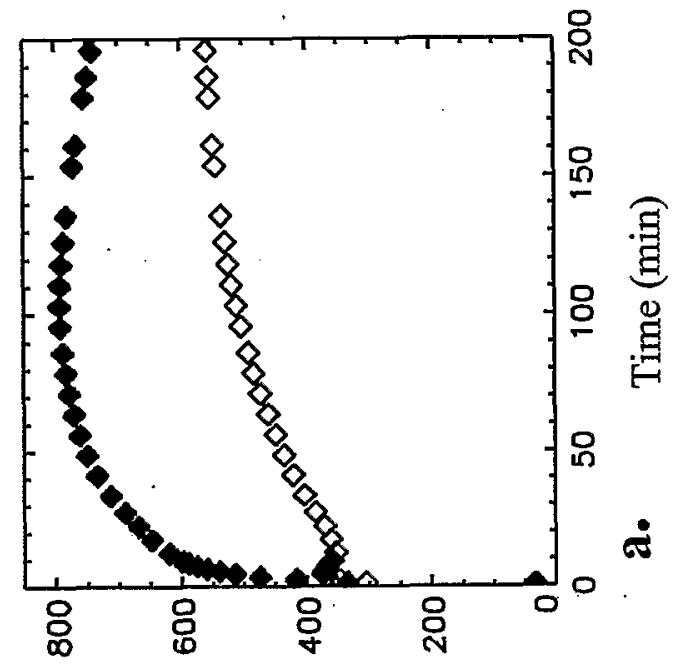

峁 כo/วsođ \% 


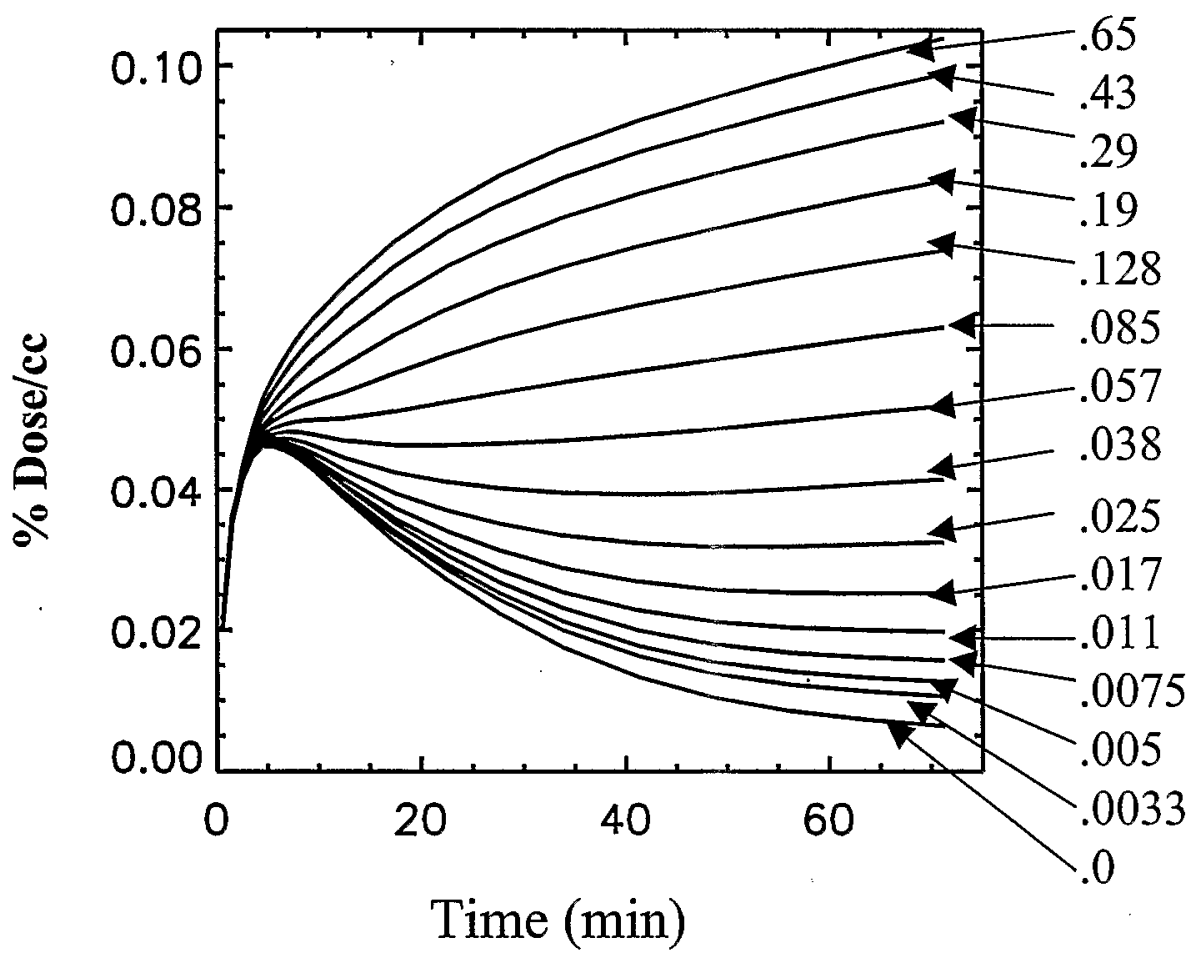

Figure 2 


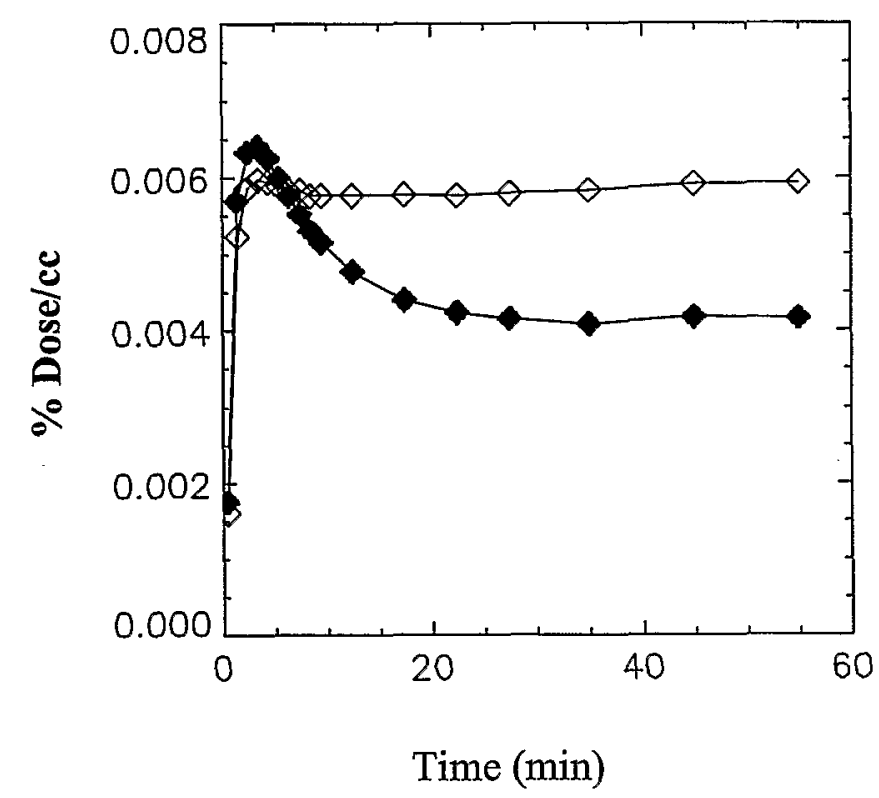

Figure 3 


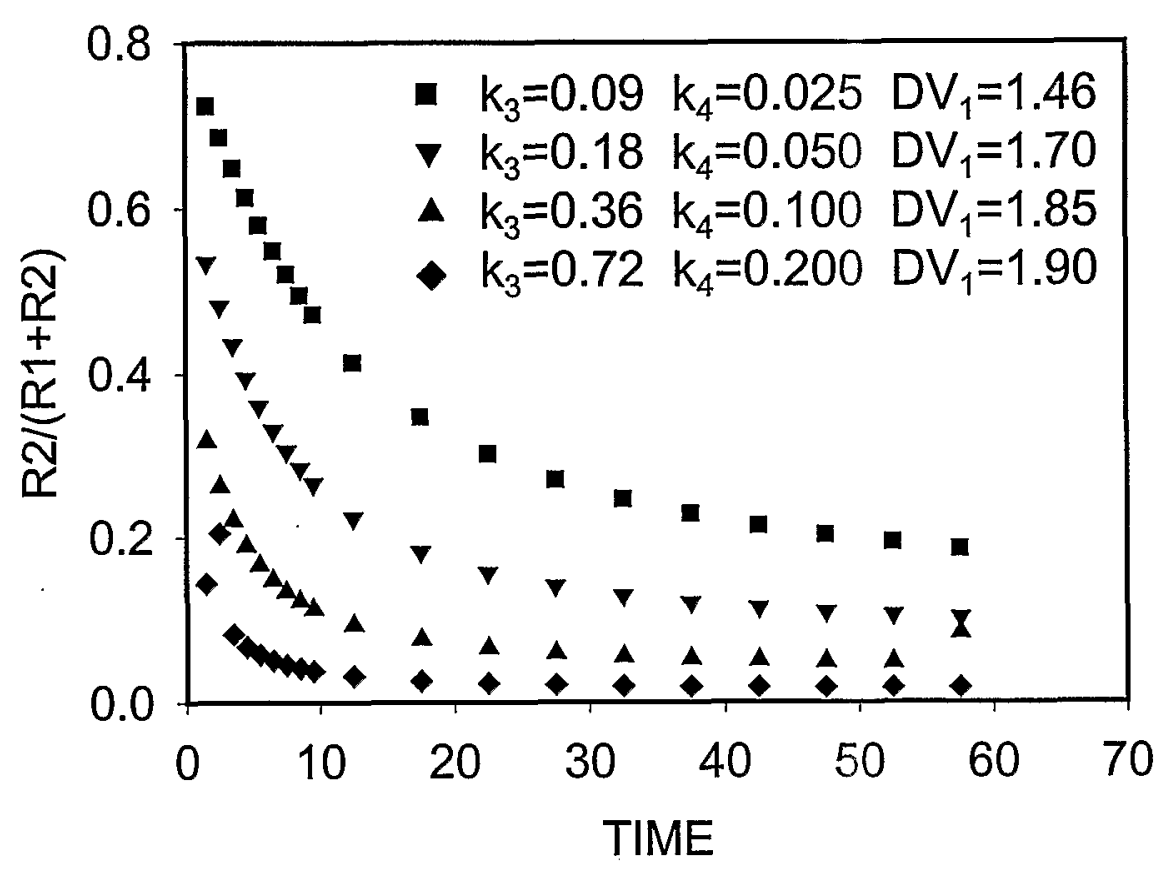

Figure 4 